\title{
Revision of Desmodorinae and Spiriniinae (Nematoda: Desmodoridae) with redescription of eight known species
}

\author{
Maickel ARMENTEROS ${ }^{1}$, Alexei RUIZ-ABIERNO ${ }^{2} \&$ Wilfrida DECRAEMER ${ }^{3}$ \\ ${ }^{1,2}$ Centro de Investigaciones Marinas, Universidad de La Habana, Calle 16 Número 114, Playa, \\ CP 11300, Habana, Cuba. \\ Email: maickel@cim.uh.cu (corresponding author) \\ ${ }^{3}$ Royal Belgian Institute of Natural Sciences, rue Vautier 29, B-1000, Brussels, Belgium. \\ alexei@cim.uh.cu \\ ${ }^{3}$ Biology Department, Ghent University, Ledeganckstraat 35, B-9000, Gent, Belgium. \\ wilfrida.decraemer@naturalsciences.be \\ ${ }^{1}$ urn:Isid:zoobank.org:author:869FA865-9251-489D-B399-1BA828530C6D \\ ${ }^{2}$ urn:lsid:zoobank.org:author:4D8DE0FF-2CC1-4DD4-BE52-4C2E5B1527DF \\ ${ }^{3}$ urn:1sid:zoobank.org:author:61262451-D994-411F-8331-1EB9AFACA48C
}

\begin{abstract}
The taxonomy of the family Desmodoridae (Nematoda: Desmodorida) is partially revised based on morphology. The diagnoses of the Desmodoridae and the subfamilies Desmodorinae and Spiriniinae are emended to accommodate re-analyzed morphological features. Eight known species are redescribed and the implication of the new findings for the taxonomy of the group is discussed. Amphispira and Metadesmodora are confirmed as genera inquirendae. Alaimonema and Sigmophoranema, and their corresponding type species, are proposed as inquirendae due to poor descriptions of the type material. The other three species of Sigmophoranema are transferred to the genus Onyx because they bear the diagnostic features of this group: spear-like dorsal tooth and s-shape precloacal supplements. Echinodesmodora, Paradesmodora and Stygodesmodora are transferred to the Spiriniinae based on the absence of a head capsule and on the amphidial fovea being surrounded by cuticle striation. Paradesmodora toreutes is transferred to the genus Acanthopharyngoides as A. toreutes comb. nov. The genus Onepunema does not fit in the family Desmodoridae because of diorchic males; thus, it is regarded as taxon incertae sedis. Lists of valid genera for the two subfamilies are provided. A dichotomic key for the identification of the 14 genera within the Spiriinae is provided.
\end{abstract}

Keywords. Taxonomy, systematic, revision, morphology, Cuba.

Armenteros M., Ruiz-Abierno A. \& Decraemer W. 2014. Revision of Desmodorinae and Spiriniinae (Nematoda: Desmodoridae) with redescription of eight known species. European Journal of Taxonomy 96: 1-32. http://dx.doi. org/10.5852/ejt.2014.96

\section{Introduction}

The family Desmodoridae Filipjev, 1922 includes a diverse and heterogeneous group of free-living, mostly marine, nematodes (Decraemer \& Smol 2006). Desmodorid nematodes are very abundant in 
habitats such as tropical coral reefs (Tietjen 1991), sandy beaches (Verschelde \& Vincx 1996) and seagrass beds (Ndaro \& Ólafsson 1999), but also occur in deep-sea (Verschelde et al. 1998; Fonseca Cavalcanti et al. 2009) and freshwater habitats (Decraemer \& Smol 2006). The species within the family probably are an important component of the functional diversity of benthic food webs due to their varied morphology and symbiotic relationships with bacteria (Ott 1996). They constitute the most abundant group in the marine sediments from a tropical coral reef in Punta Francés, Cuba, Caribbean Sea (Armenteros et al. 2012) and deserve a more thorough taxonomic study.

The family Desmodoridae belongs to the superfamily Desmodoroidea Filipjev, 1922, together with the families Draconematidae Filipjev, 1918 and Epsilonematidae Steiner, 1927. It is composed of six subfamilies, 35 genera and 318 species (Hodda 2011); but these figures may vary according to the source (e.g., 320 valid marine species in the World Register of Marine Species, accessed February 2014). The six subfamilies currently recognized (Decraemer \& Smol 2006) are: Desmodorinae Micoletzky, 1924, Molgolaiminae (Jensen, 1978), Prodesmodorinae Lorenzen, 1981, Pseudonchinae Gerlach \& Riemann, 1973, Spiriniinae Gerlach \& Murphy, 1965 and Stilbonematinae Chitwood, 1936.

Several recent taxonomic studies dealt with taxa of the Desmodoridae (e.g., Blome \& Riemann 1994; Verschelde et al. 1998, 2006). Five faunistic studies (Gerlach 1950, 1963; Wieser 1954; Wieser \& Hopper 1967; Boucher 1975) described several species of desmodorids and proposed dichotomic keys to species. Further revisions (and/or identification keys) for specific genera within the family have been published, e.g., for Chromadoropsis Filipjev, 1918 (Furstenberg \& Vincx 1988), Chromaspirina Filipjev, 1918 (Maria et al. 2009), Croconema Cobb, 1920 (Verschelde et al. 2006), Desmodora de Man, 1889 (Verschelde et al. 1998), Laxus Cobb, 1894 (Ott et al. 1995), Metachromadora Filipjev, 1918 (Maria et al. 2014), Onyx Cobb, 1891 (Dinh Tu et al. 2011), Perspiria (Wieser \& Hopper, 1967) (Vincx \& Gourbault 1989), Pseudonchus Cobb, 1920 (Warwick 1969) and Spirinia Gerlach, 1963 (Coles 1987). Recently, the subfamily Stilbonematinae has also been revised (Tchesunov 2013; Armenteros et al. 2014). In the recently published Handbook of Zoology, Tchesunov (2014) provided an overview of the order Desmodorida.

The family Desmodoridae lacks any synapomorphy. It may be distinguished from the Draconematidae and Epsilonematidae by elimination taking into account the synapomorphies of these families: the distinctive body shape with swollen pharyngeal region and the presence of specialized somatic setae (Lorenzen 1994). Molecular evidence, based upon small subunit of ribosomal DNA (SSU rDNA), indicated that the family Desmodoridae is highly polyphyletic (van Megen et al. 2009). Even more, the systematics of the family is poorly understood, because (1) morphological characters are conflictive to unravel the relationships among taxa (Kampfer et al. 1998) and (2) phylogenetic analyses (Armenteros et al. in press) suggested the non-monophyletic nature of the subfamilies Desmodorinae and Spiriniinae and stressed the necessity to collect more data of previously non-sequenced genera and species. Additionally, the taxonomy of the Desmodoridae suffers from morphologically poorly defined taxa (e.g., Laxonema Cobb, 1933; Metadesmodora Schuurmans Stekhoven, 1942), lack of identification keys to some speciose genera (e.g., Desmodora de Man, 1889) and the absence of updated species lists.

A possibly effective approach to deal with this taxonomic problem is to carry out revisions of taxa in order to clarify, organize and compile taxonomic information (Wheeler 2004). We hereby used the morphological species concept based on the discontinuous variation of morphological features. Our approach is based on the differential fitness species concept (Hausdorf 2011), which allows the recognition of differences based on phenotypic clusters.

We identified 14 species belonging to three subfamilies of the Desmodoridae collected from the Punta Francés coral reef (Cuba). A first study dealt with six new and known species of the Stilbonematinae 
(Armenteros et al. 2014). The available new material from Cuba allows a more detailed study of the morphology of known eight species belonging to the subfamilies Desmodorinae and Spiriniinae. The aim of the present contribution is a taxonomic revision of the subfamilies Desmodorinae and Spiriniinae. We provide: (1) emended diagnoses of the family and subfamilies, (2) comparative descriptions of the morphology of the species, with emphasis on the new findings arisen from our observations with interference light microscope (LM) and scanning electronic microscope (SEM), (3) an outline of the proposed taxonomic changes, (4) lists of valid genera for both subfamilies and (5) a dichotomic key to genus level for the Spiriniinae.

\section{Material and methods}

\section{Collection and processing of samples}

Nematodes were collected in the SW region of Cuban Archipelago, Punta Francés Reef $\left(21^{\circ} 36^{\prime} 29.68^{\prime \prime} \mathrm{N}\right.$, $83^{\circ} 10^{\prime} 34.40^{\prime \prime} \mathrm{W}$ ) during two sampling campaigns in July 2009 and July 2010. The collection site had conditions typical of coral reefs: salinity of 35.5 , temperature of $28^{\circ} \mathrm{C}$, dissolved oxygen of $6-7 \mathrm{mg} \mathrm{L}^{-1}$ and average depth of $2 \mathrm{~m}$. Sediment samples were collected manually with plastic cores (syringes 2.6 $\mathrm{cm}$ diameter) from sand flats with scarce vegetation and seagrass meadows of Thalassia testudinum Banks ex König.

In the field, samples were sieved over a $45 \mu \mathrm{m}$ mesh and preserved in $96 \%$ ethanol until processing in the laboratory. Nematodes were extracted from the samples, left for 36 hours in a mixture of ethanol and glycerin within an incubator at $35{ }^{\circ} \mathrm{C}$ and afterwards mounted on glass slides following the procedure proposed by Vincx (1996).

\section{Identification and morphological description}

Measurements and drawings of specimens were done using a light microscope (LM) Leica DM2500 with interference contrast and drawing tube attachment. LM images were taken with a Color View digital camera coupled to a microscope Olympus BX41 with interference contrast and using the software Olympus cell ${ }^{\wedge} \mathrm{D}$. High magnification images were taken with a scanning electronic microscope (SEM) FEI Quanta 200, specimens used for SEM could not be included in LM observations.

The species identification was based on the taxonomic literature and on the database NeMys that recently migrated to the World Register of Marine Species (http://www.marinespecies.org). The invaluable checklist by Gerlach \& Riemann (1973) has been used to double check for nomenclature and authorship issues.

For each species, we measured ten specimens per gender (i.e., male, female) and ten juveniles. Twelve morphometric variables were measured or calculated (Tables 1 and 2). We recorded other morphological characters that are valuable for species differentiation within the Desmodoridae such as cuticle striation, head capsule, relative position of cephalic sensilla, additional subcephalic setae, somatic setal pattern, shape and position of the amphidial fovea, buccal armature, pharynx structure, pre- and post-cloacal supplements and tail shape. This study includes only known species and therefore we offer a condensed description of the species, highlighting only those features that are new (e.g., body measures) or important for the taxonomy of the species.

The type material was revised, based on LM photographs of the type specimens of Paradesmodora sinuosa Ott, 1972 and P. toreutes Wieser \& Hopper, 1967. Microscopic pictures were taken by the curators of the collections at the Smithsonian National Museum of Natural History (Washington, D.C.) and Canadian National Collection of Nematodes, respectively, since type material is no longer sent by mail to avoid loss or damage of type specimens. 


\section{List of abbreviations}

af $=$ amphidial fovea

bcc $=$ border of head capsule

blr $=$ border of lip region

$\mathrm{cl}=$ cloacal opening

$\mathrm{cs}=$ cephalic setae

ils $=$ inner labial sensilla

ols $=$ outer labial sensilla

ps $=$ precloacal supplement

scs $=$ subcephalic setae

$\mathrm{sp}=$ spinneret

ss $=$ somatic setae (in Fig. 3 lss $=$ large somatic setae, sss $=$ short somatic setae)

str $=$ cuticle striation

tb $=$ tail bent (curvature)

tp $=$ tail punctations

va $=$ vulva

\section{Results}

The results have been structured in the following order: hierarchy and diagnosis of the family, diagnoses and species descriptions for subfamilies Desmodorinae and Spiriniinae, taxa proposed as inquirendae, taxa with new classification, list of valid genera for both treated subfamilies, and identification key to genera within Spiriniinae.

Phylum Nematoda Cobb, 1932

Class Chromadorea Inglis, 1983

Subclass Chromadoria Adamson, 1987

Order Desmodorida de Coninck, 1965

Suborder Desmodorina de Coninck, 1965

Superfamily Desmodoroidea Filipjev, 1922

Family Desmodoridae Filipjev, 1922

\section{Type genus}

Desmodora de Man, 1889 (syn. Mastodex Steiner, 1921: 25).

Diagnosis (emended from Decraemer \& Smol 2006)

Amphidial fovea spiral, variable (mostly in Stilbonematinae). Pharynx with muscular posterior bulb except in Stilbonematinae with a tripartite pharynx with marked anterior procorpus, narrower isthmus and posterior bulb. Tail conical (rarely conical-cylindrical, only in Perspiria and Spirodesma Cavalcanti et al., 2009). Gubernaculum mostly with apophysis dorsally oriented (rarely with dorso-caudal orientation, only in Adelphos Ott, 1997, Catanema Cobb, 1920, Parabostrichus Tchesunov, Ingels \& Popova, 2012 and Robbea Gerlach, 1956).

There are three changes hereby proposed to the diagnosis by Decraemer and Smol (2006). First, the variable shape of the amphidial fovea (i.e., one to two turns) also at subfamily level, e.g., the mostly cryptospiral amphidial fovea in Desmodorinae and Spiriniinae can be a spiral of 1-2 turns in Stilbonematinae (Eubostrichus Greeff, 1869, Laxus) or a shepherd's crook (Leptonemella Cobb, 1920) or reduced to the aperture of the canalis amphidialis (Stilbonema Cobb, 1920). Second, the exception of conical-cylindrical tail to include the genera Perspiria and Spirodesma. Third, the correction of 
apophysis orientation, which is mostly dorsally oriented except in four genera of Stilbonematinae (Adelphos, Catanema, Parabostrichus and Robbea). The scarcity of diagnostic features and the number of exceptions reflexes the morphological diversity of this family.

Subfamily Desmodorinae Micoletzky, 1924

\section{Type genus}

Desmodora de Man, 1889 (syn. Mastodex Steiner, 1921: 25).

Diagnosis [emended from Decraemer \& Smol (2006) and Verschelde et al. (2006)]

Head capsule conspicuous, characterized by the thickened cuticle and mostly with an external demarcation between labial and cephalic regions, except in Sibayinema Swart \& Heyns, 1991 (Verschelde et al. 2006). Amphidial fovea not surrounded by cuticle striations (but the posterior border of the fovea may contact the first annuli). Buccal cavity always with distinct teeth. Cuticle usually coarsely striated.

The diagnosis proposed by Verschelde et al. (2006) was expanded to include other features (e.g., demarcation between labial and cephalic region, buccal cavity) and we extended the presence of body coarse annuli as diagnostic feature for the subfamily. The modifications to the diagnosis by Decraemer and Smol (2006) were mainly the addition of the external demarcation as diagnostic feature and the deletion of the pharyngeal bulb that is a diagnostic feature to family level.

Genus Acanthopharynx Marion, 1870

Acanthopharynx denticulatus Wieser, 1954

Figs 1A-D, 2, Table 1

Acanthopharynx denticulatus Wieser, 1954: 36.

\section{Material examined}

$10 \widehat{\partial} \hat{\partial}, 10$ 우 and 10 juveniles, deposited in the nematode collection at Centro de Investigaciones Marinas, Universidad de La Habana, CUBA.

\section{Description}

Cuticle strongly striated in the anterior part (annuli width $\sim 1 \mu \mathrm{m}$ ) becoming finer at mid-body. Head capsule well developed. Six inner and six outer labial setae, both sets papilliform. Four cephalic setiform sensilla 4-8 $\mu \mathrm{m}$ long. Two circles of 10-12 subcephalic setae, $6-8 \mu \mathrm{m}$ long and very close to each other. One pair of sublateral setae 4-6 $\mu \mathrm{m}$ long at level of amphidial fovea. Amphidial fovea cryptospiral located in the head capsule and not surrounded by cuticle striations. Eight longitudinal rows of short somatic setae $(<5 \mu \mathrm{m})$ running along the anterior body region, continuing as six longitudinal rows at mid-body and four rows on the tail. Buccal cavity with 12 cheilorhabdia, one large dorsal tooth and two smaller ventrosublateral teeth, a transverse row of 7-10 minute denticles at level of tip dorsal tooth. Pharynx meandering with posterior widened bulb marked by several plasmatic interruptions, internal lining well sclerotized. Cardia not conspicuous. Secretory-excretory system not observable. End portion of tail smooth, showing a characteristic ventral bend; spinneret well developed.

Male monorchic, the anterior testis to the right of the intestine. Spicules strongly bent, with capitulum, gubernaculum a straight rod oriented dorsally. Precloacal ventromedian supplements (13-16) visible as small pits located on a cuticular ridge. 

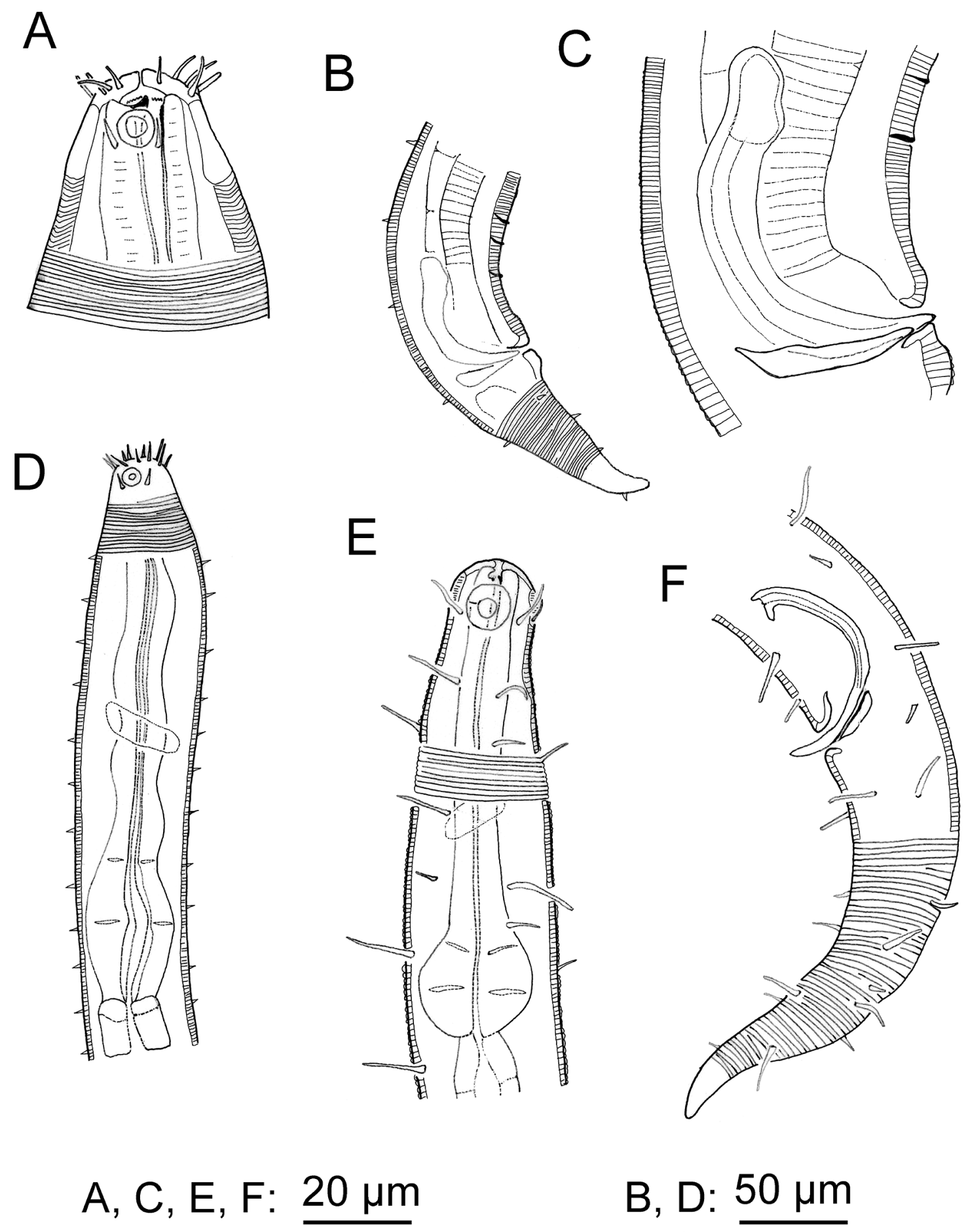

Fig. 1. A-D. Acanthopharynx denticulatus Wieser, 1954, Ô. A. Head region. B. Tail region. C. Copulatory apparatus. D. Neck region. E-F. Bolbonema brevicolle Cobb, 1920, §. E. Neck region. F. Posterior region with tail end in surface view. 
Female didelphic, ovaries antidromously reflexed, anterior genital branch to the right of the intestine, posterior genital branch to the left.

Juveniles are similar to adults except for the development of the reproductive system.

\section{Remarks}

At present, the genus Acanthopharynx Marion, 1870 includes 11 valid species. A dichotomous key to eight of the species was published by Wieser (1954). At least two species, A. brachycapitata Allgén,
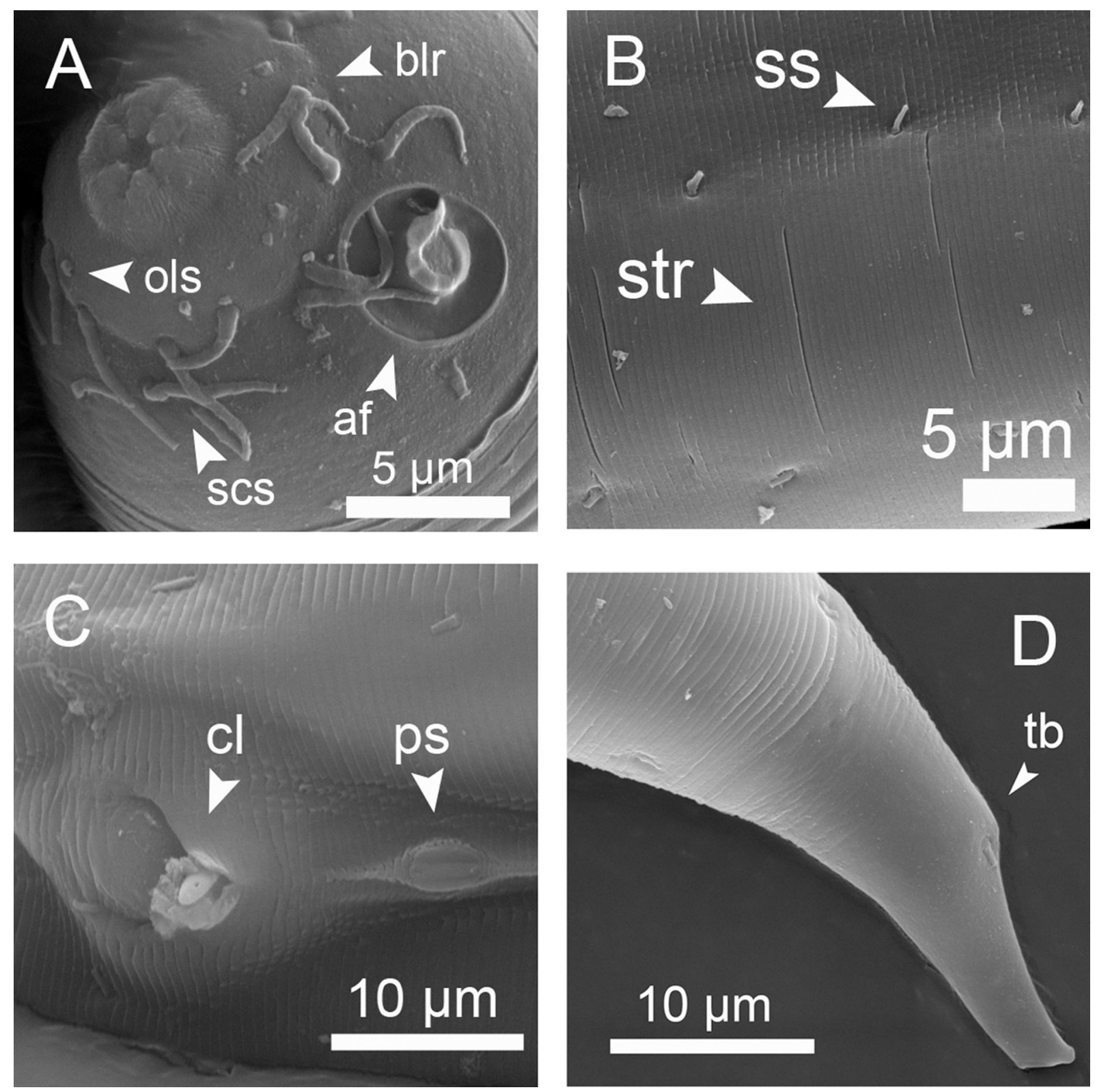

Fig. 2. Acanthopharynx denticulatus Wieser, 1954, SEM microphotographs of $\partial$. A. Head oblique en face view. B. Cuticle striation at mid-body. C. Cloacal region, from a different $\hat{\sigma}$ specimen than A, B and D. D. Tail tip, showing ventral bent. 
1947 (Allgén 1947: 148) and A. similis Allgén, 1932, have to be regarded as species inquirendae due to their poor description. The differences among the Acanthopharynx species are subtle and consequently their identification is quite difficult. The features with diagnostic values are the relative size and shape of amphidial fovea, number of subcephalic setae, presence/absence of denticles, de Man ratio a, number of precloacal supplements and length of spicules and gubernaculum. For instance, A. denticulatus differs from A. rigida Schuurmans Stekhoven, 1950 only in the presence of a row of tiny denticles that are not easy to observe. The specimens of $A$. denticulatus described in this work fit the original description by Wieser (1954) apart from a larger body length of type specimens (male: 2170-2780 $\mu \mathrm{m}$, female: $2600 \mu \mathrm{m}$ ) vs ours (male: $1234-1745 \mu \mathrm{m}$, female: $1299-1796 \mu \mathrm{m}$ ). However, we regard these differences as intraspecific variation among populations.

Genus Bolbonema Cobb, 1920

Bolbonema brevicolle Cobb, 1920

Figs 1E-F, 3, Table 1

Bolbonema brevicolle Cobb, 1920: 264.

Desmodora (Bolbonema) brevicolle - Gerlach 1963: 90.

\section{Material examined}

$6 \hat{\partial} \widehat{\partial}, 7$ 우 and 1 juvenile, deposited in the nematode collection at Centro de Investigaciones Marinas, Universidad de La Habana, CUBA.

\section{Description}

Cuticle annulated in the anterior region (annuli $0.6-0.8 \mu \mathrm{m}$ width) becoming finely striated at midbody $(0.2-0.3 \mu \mathrm{m})$. Head capsule well developed, surface appearing with a fingerprint pattern by LM, SEM microphotographs suggest some depressions in the surface. Six inner and six outer labial sensilla papilliform. Four cephalic sensilla (10-13 $\mu \mathrm{m}$ long) at the base of the head capsule, four subcephalic setae (6-8 $\mu \mathrm{m}$ long) next to the cephalic ones. Amphidial fovea cryptospiral, relatively large, posterior border is in contact with cuticle striations. Eight longitudinal rows of somatic setae running from cervical region to level of anus; long setae (18-22 $\mu \mathrm{m}$ long) alternate with two shorter setae $(\sim 4 \mu \mathrm{m}$ long). Buccal cavity small, with one small dorsal tooth and two ventrosublateral denticles, not always visible. Pharynx muscular with well-developed posterior bulb and plasmatic interruptions. Cardia and excretory-secretory system not observable. Tail region with only four longitudinal rows of setae.

Male monorchic; anterior testis to the right of the intestine. Spicule capitulum with a characteristic ventral process. No precloacal supplements.

Female didelphic, ovaries antidromously reflexed and both genital branches to the right of the intestine. Vulva a simple transversal slit-like aperture.

Juveniles are similar to adults except for the development of the reproductive system.

\section{Remarks}

Our specimens largely agree with the original description of this species by Cobb (1920) and redescriptions by Gerlach (1963) and Pastor de Ward (1988). The single clear difference in our specimens is the presence of four subcephalic setae in subdorsal and subventral positions slightly smaller than the four cephalic sensilla and inserted closely to the latter (Fig. 3B). These setae were clearly visible with SEM and could have been overlooked by mentioned authors in LM; actually, we could not see them clearly in 
all specimens. The body length shows some variation for the different populations with a considerably smaller female $(737 \mu \mathrm{m})$ described by Gerlach (1963), and larger specimens described by Pastor de Ward (1988) (range: 1550-1950 $\mu \mathrm{m}$ ). The range of body length of our specimens is more in agreement with the type specimens (males: 1051-1372 $\mu \mathrm{m}$, females: $942-1387 \mu \mathrm{m}$ ) and it is closer to the holotype described by Cobb (1920) (female: $\sim 1300 \mu \mathrm{m}$ ). The cuticle heterogeneity in annulation is quite marked in $B$. brevicolle with the anterior annuli being rings three-fold wider than the striation in the posterior region; however, this feature has not been mentioned in previous descriptions.
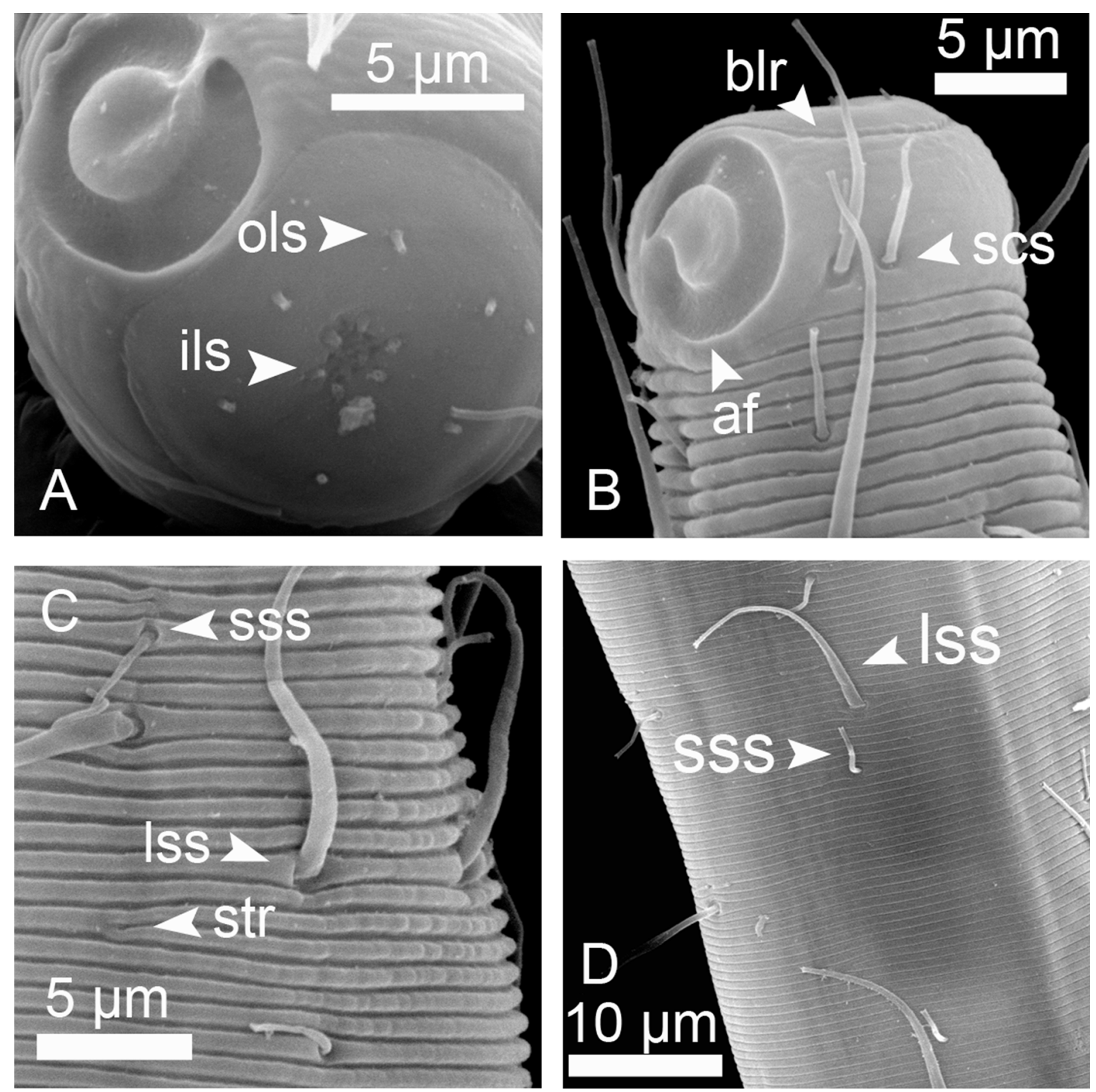

Fig. 3. Bolbonema brevicolle Cobb, 1920, SEM microphotographs of $\widehat{\partial}(\mathrm{A})$ and $\subsetneq$ (B, C \& D). A. Head in oblique en face view. B. Head in oblique lateral view. C. Cuticle striation at anterior region. D. Cuticle striation at mid-body region. 
Table 1. Mean (range) of morphological measures for five nematode species of the subfamily Desmodorinae from the Punta Francés coral reef, Cuba. $\mathrm{N}=$ number of specimens, $\mathrm{J}=$ juvenile. For each variable the first row corresponds to males, the second to females and the third to juveniles. Abbreviations: a.b.d. $=$ anal body diameter; Amp. Fovea c.b.d. $=$ relation of amphidial fovea diameter to corresponding body diameter; de Man ratios are the relation of body length to body diameter (a), to pharynx length (b) and to tail length (c) respectively; $\mathrm{c}^{\prime}=$ relation of tail length to anal body diameter, $\mathrm{V} \%=$ distance (relative to body length) of vulva to anterior end.

\begin{tabular}{|c|c|c|c|c|c|}
\hline Species/Variable & $\begin{array}{c}\text { Acanthopharynx } \\
\text { denticulatus }\end{array}$ & $\begin{array}{c}\text { Bolbonema } \\
\text { brevicolle }\end{array}$ & $\begin{array}{l}\text { Croconema } \\
\text { cinctum }\end{array}$ & $\begin{array}{c}\text { Desmodora } \\
\text { pontica }\end{array}$ & $\begin{array}{r}\text { Zalonema } \\
\text { ditlevseni }\end{array}$ \\
\hline $\mathbf{N}$ & $10 \hat{\jmath}, 10$ क,$+ 10 \mathrm{~J}$ & $6 \hat{\jmath} \hat{\jmath}, 7 q+1,1 \mathrm{~J}$ & $10 \bigcirc^{\wedge}, 9$ 우, $10 \mathrm{~J}$ & $10 \widehat{\jmath}, 10$ q,$+ 11 \mathrm{~J}$ & 10 ๙ิ่, 10 우, $10 \mathrm{~J}$ \\
\hline $\begin{array}{l}\text { Body length } \\
(\mu \mathrm{m})\end{array}$ & $\begin{array}{c}1533(1234-1745) \\
1487(1299-1796) \\
1084(847-1387)\end{array}$ & $\begin{array}{c}1157(1051-1372) \\
1143(942-1387) \\
869\end{array}$ & $\begin{array}{c}2016(1528-2475) \\
2237(1270-2781) \\
972(518-2095)\end{array}$ & $\begin{array}{c}1320(1037-1555) \\
1288(1029-1431) \\
1016(613-1438)\end{array}$ & $\begin{array}{c}1201(847-2022) \\
1088(898-1380) \\
807(402-1329)\end{array}$ \\
\hline de Man ratio a & $\begin{array}{l}28(24-43) \\
27(21-37) \\
27(21-39)\end{array}$ & $\begin{array}{c}33(30-39) \\
30(24-37) \\
32\end{array}$ & $\begin{array}{l}34(23-64) \\
30(23-60) \\
23(16-36)\end{array}$ & $\begin{array}{l}31(25-36) \\
24(18-28) \\
26(18-32)\end{array}$ & $\begin{array}{l}22(17-28) \\
26(20-32) \\
20(16-26)\end{array}$ \\
\hline de Man ratio b & $\begin{array}{l}6(5-7) \\
6(5-6) \\
6(5-7)\end{array}$ & $\begin{array}{c}14(12-16) \\
14(13-16) \\
13\end{array}$ & $\begin{array}{c}12(9-19) \\
12(9-20) \\
8(5-13)\end{array}$ & $\begin{array}{c}9(8-10) \\
10(7-17) \\
9(5-10)\end{array}$ & $\begin{array}{l}8(7-10) \\
8(7-10) \\
7(5-9)\end{array}$ \\
\hline de Man ratio c & $\begin{array}{l}19(16-21) \\
18(16-21) \\
14(11-16) \\
\end{array}$ & $\begin{array}{c}13(12-14) \\
14(13-15) \\
12\end{array}$ & $\begin{array}{c}19(13-27) \\
25(18-37) \\
11(7-20) \\
\end{array}$ & $\begin{array}{c}16(13-19) \\
15(13-18) \\
14(9-21) \\
\end{array}$ & $\begin{array}{c}14(10-21) \\
11(5-14) \\
10(6-16) \\
\end{array}$ \\
\hline $\begin{array}{l}\text { Amp. fovea c.b.d. } \\
(\%)\end{array}$ & $\begin{array}{l}31(25-34) \\
31(27-34) \\
30(24-35) \\
\end{array}$ & $\begin{array}{c}53(48-57) \\
50(44-60) \\
42 \\
\end{array}$ & $\begin{array}{l}16(15-17) \\
20(14-35) \\
21(16-26) \\
\end{array}$ & $\begin{array}{l}33(26-43) \\
31(26-35) \\
31(26-38)\end{array}$ & $\begin{array}{l}30(23-36) \\
35(27-40) \\
32(28-40)\end{array}$ \\
\hline $\begin{array}{l}\text { Pharynx length } \\
(\mu \mathrm{m})\end{array}$ & $\begin{array}{l}262(220-284) \\
253(214-286) \\
189(153-240) \\
\end{array}$ & $\begin{array}{c}88(74-95) \\
81(73-88) \\
69 \\
\end{array}$ & $\begin{array}{c}175(106-213) \\
187(130-219) \\
124(89-186) \\
\end{array}$ & $\begin{array}{c}143(111-158) \\
144(116-176) \\
116(88-151) \\
\end{array}$ & $\begin{array}{c}150(127-200) \\
137(116-160) \\
118(74-158) \\
\end{array}$ \\
\hline $\begin{array}{l}\text { Maximum body } \boldsymbol{} \\
(\mu \mathrm{m})\end{array}$ & $\begin{array}{l}53(38-66) \\
56(42-71) \\
42(31-60)\end{array}$ & $\begin{array}{c}35(32-39) \\
40(27-48) \\
27\end{array}$ & $\begin{array}{c}64(31-78) \\
85(44-103) \\
40(30-62)\end{array}$ & $\begin{array}{l}43(39-53) \\
55(44-80) \\
40(32-71)\end{array}$ & $\begin{array}{l}55(45-86) \\
43(37-48) \\
41(22-64)\end{array}$ \\
\hline $\begin{array}{l}\text { Tail length } \\
(\mu \mathrm{m})\end{array}$ & $\begin{array}{l}83(78-86) \\
83(77-90) \\
79(67-87)\end{array}$ & $\begin{array}{c}93(87-97) \\
84(71-93) \\
70\end{array}$ & $\begin{array}{c}107(75-123) \\
91(70-110) \\
86(60-106)\end{array}$ & $\begin{array}{l}81(71-90) \\
83(70-93) \\
75(64-93)\end{array}$ & $\begin{array}{c}84(76-110) \\
97(85-109) \\
80(61-94)\end{array}$ \\
\hline Tail length $\mathrm{c}^{\prime}$ & $\begin{array}{l}2.0(1.6-2.2) \\
2.9(2.6-3.1) \\
3.1(2.3-3.8)\end{array}$ & $\begin{array}{c}3.9(3.3-4.1) \\
4.4(4.0-4.8) \\
4.1\end{array}$ & $\begin{array}{l}2.3(2.0-2.8) \\
2.3(1.7-2.8) \\
3.3(1.9-4.3)\end{array}$ & $\begin{array}{l}2.3(2.0-2.8) \\
3.0(1.8-3.9) \\
3.0(2.2-3.8)\end{array}$ & $\begin{array}{l}2.5(1.7-3.1) \\
4.1(3.5-4.6) \\
3.2(2.2-4.6)\end{array}$ \\
\hline V\% & $53(49-59)$ & $49(46-53)$ & $58(48-60)$ & $63(51-74)$ & $48(46-51)$ \\
\hline $\begin{array}{l}\text { Spiculum length } \\
(\mu \mathrm{m})\end{array}$ & $71(64-81)$ & $42(39-48)$ & $83(47-113)$ & $61(50-69)$ & $51(41-84)$ \\
\hline $\begin{array}{l}\text { Gubernaculum } \\
\text { length }(\mu \mathrm{m})\end{array}$ & $30(25-34)$ & $13(11-15)$ & $23(16-29)$ & $26(18-32)$ & $21(14-27)$ \\
\hline
\end{tabular}

Genus Croconema Cobb, 1920

Croconema cinctum Cobb, 1920

Figs 4, 5, Table 1

Croconema cinctum Cobb, 1920: 332.

Desmodora (Croconema) cincta-Gerlach, 1963: 87. 


\section{Material examined}

$10 \widehat{\partial} \widehat{\partial}, 9 q q$ and 10 juveniles, deposited in the nematode collection at Centro de Investigaciones Marinas, Universidad de La Habana, CUBA.

\section{Description}

Cuticle coarsely striated (annuli $\sim 2 \mu \mathrm{m}$ width). Head capsule well-developed and relatively extended longitudinally. Inner labial sensilla papilliform. Outer labial sensilla setiform papillae and minute $(1-2 \mu \mathrm{m}$

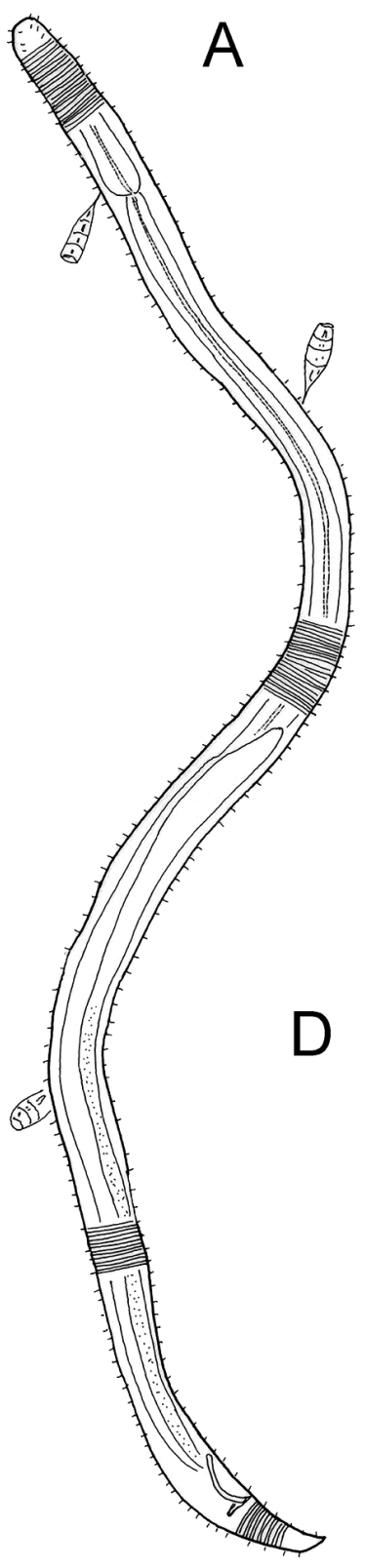

A: $200 \mu \mathrm{m}$
$\mathrm{B}$
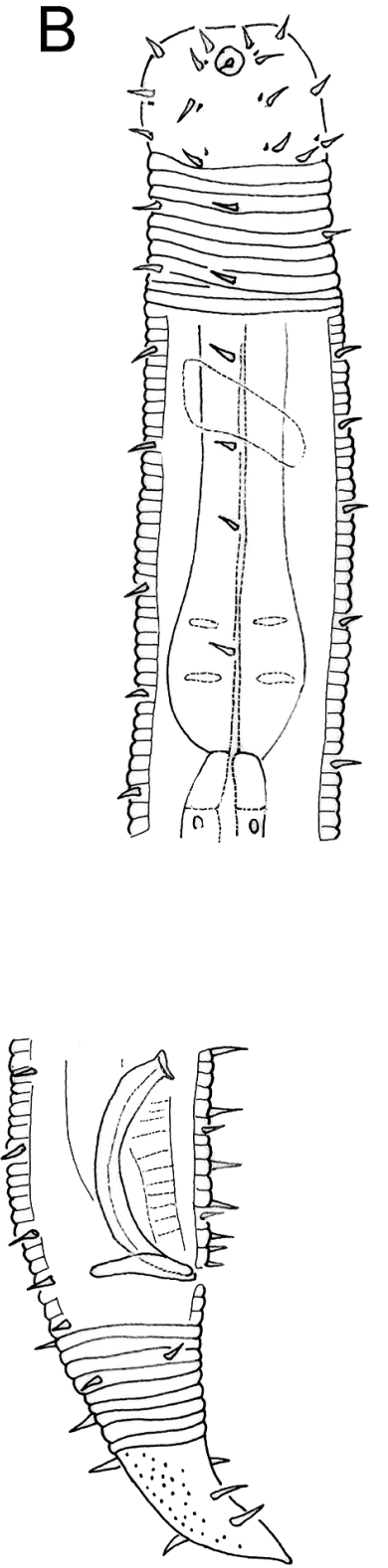

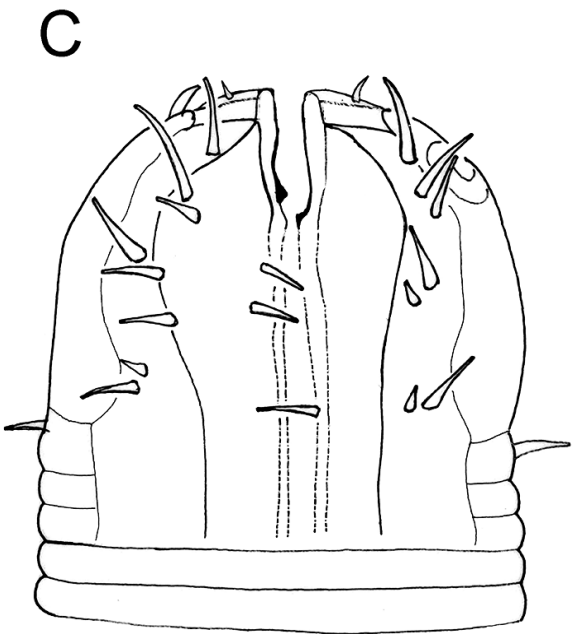

$E$

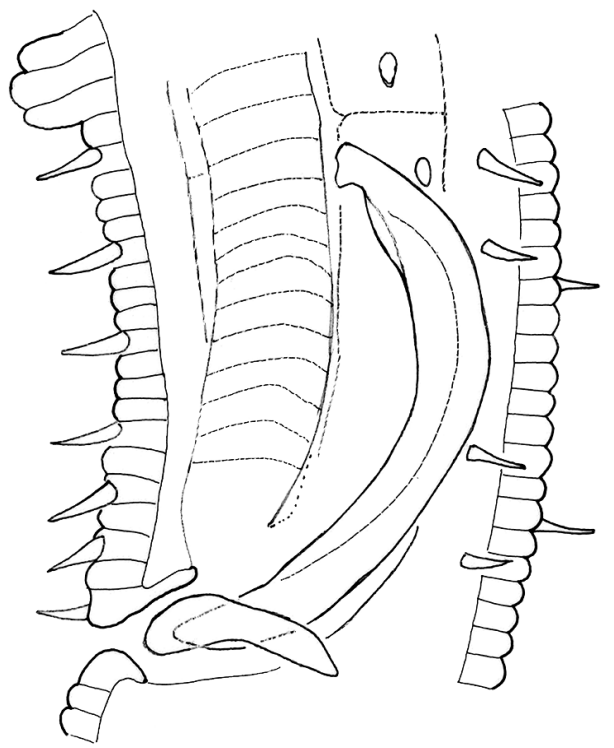

C, E: $\underline{20 \mu \mathrm{m}}$

Fig. 4. Croconema cinctum Cobb, 1920, §̂ specimen 1 (A, B \& D) and specimen 2 (C \& E). A. Habitus. B. Neck region. C. Head. D. Tail region. E. Copulatory apparatus. 
long). Four cephalic setiform sensilla (5-10 $\mu \mathrm{m}$ long); three circlets of eight subcephalic setae (5-10 $\mu \mathrm{m}$ long) on the head capsule: the first circle very close to cephalic sensilla, the second circle posterior to the amphidial fovea and the third circle close to the posterior border of the capsule. Amphidial fovea cryptospiral, relatively small and located ahead in the capsule. Eight longitudinal rows of short somatic setae (4-5 $\mu \mathrm{m}$ long) running along body length, at the posterior region continuing as six rows. Buccal cavity narrow, elongate, with one dorsal tooth and two minute ventrosublateral teeth. Pharynx muscular with posterior bulb. Cardia extended. Secretory-excretory system not observable. Tail non-striated in the last third, conspicuously punctuated and with few scattered subterminal setae $(2-3 \mu \mathrm{m}$ long).

Male monorchic, anterior testis to the right of the intestine. Spicule curved, slightly cephalated, gubernaculum a narrow cuticularized rod. Two ventromedian precloacal supplements formed by the
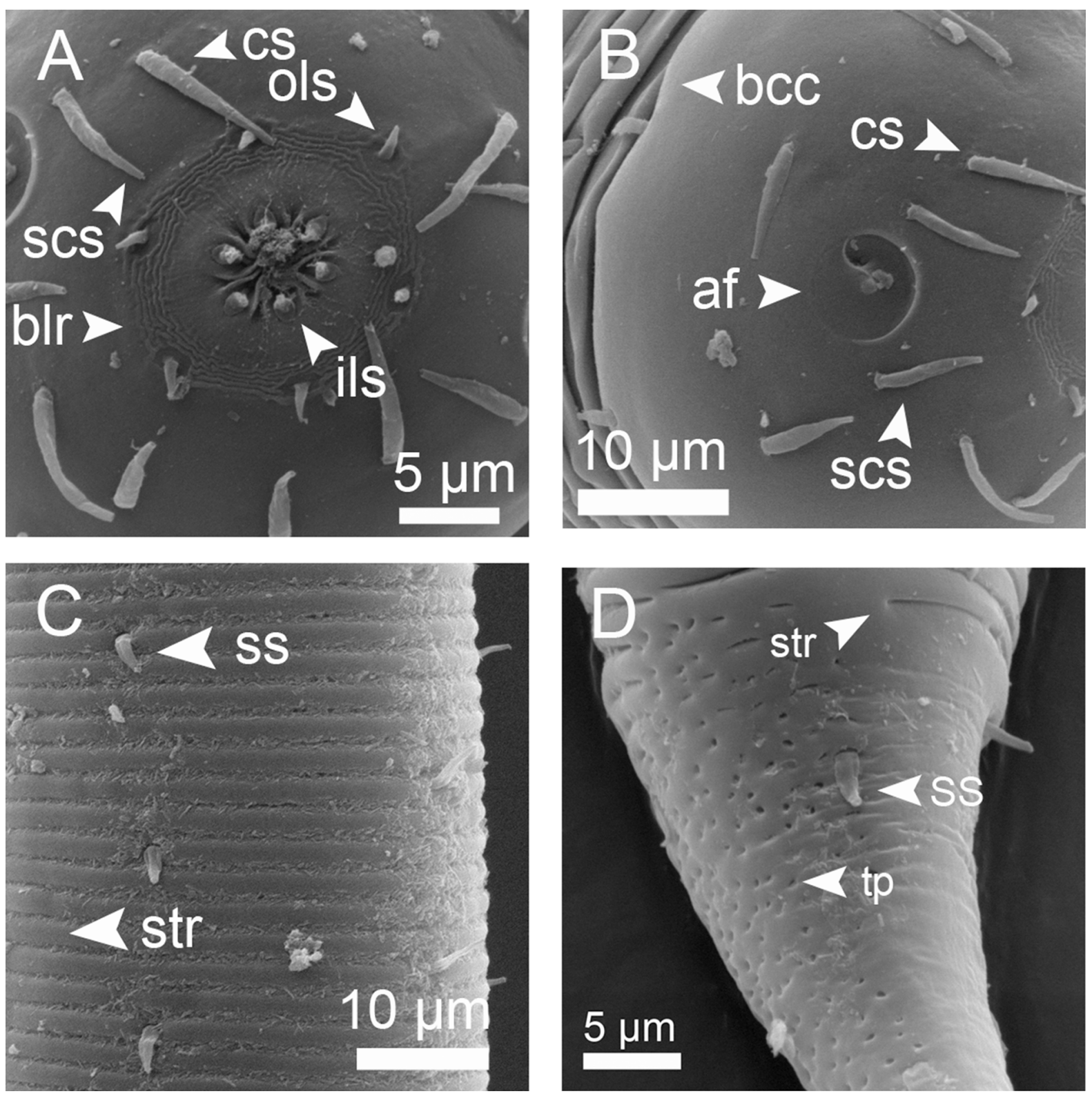

Fig. 5. Croconema cinctum Cobb, 1920, SEM microphotographs of $\widehat{o}$ specimen 1 (A, B \& D) and specimen 2 (C). A. Labial region, en face view. B. Head capsule, lateral view. C. Cuticle striation at mid-body region. D. Part of tail tip. 
enlargement/protrusion of three consecutive annuli (mid one larger than others) (only one supplement is depicted in Fig. 4E).

Female didelphic, ovaries antidromously reflexed, anterior genital branch to the left, posterior to the right, vulva a transversal slit.

Juveniles. Juveniles are similar to adults except for the development of the reproductive system.

\section{Remarks}

Verschelde et al. (2006) proposed a dichotomous key and a table with diagnostic features for the genus Croconema. Cuban specimens are quite similar to the holotype described by Cobb (1920) and to those described from the Maldives (Gerlach 1963) and the Red Sea (Gerlach 1964). We noted in some specimens the presence of additional smaller setae at the base of the subcephalic setae (Fig. 4B-C), but we could not reveal more evidence to allow identification with another Croconema species.

Genus Desmodora de Man, 1889

Desmodora pontica Filipjev, 1922

Figs $6 \mathrm{~A}-\mathrm{B}, 7$, Table 1

Desmodora pontica Filipjev, 1922: 119.

Desmodora (Pseudochromadora) pontica - Gerlach 1963: 84.

\section{Material examined}

$10 \widehat{\jmath}, 10$ 우 and 11 juveniles, deposited in the nematode collection at Centro de Investigaciones Marinas, Universidad de La Habana, CUBA.

\section{Description}

Cuticle coarsely striated (annuli $\sim 2 \mu \mathrm{m}$ width) in the anterior region but finer at mid-body region (annuli $\sim 1 \mu \mathrm{m}$ width). Strong head capsule with labial region clearly marked by a suture. Inner labial setae papilliform. Outer labial sensilla relatively long ( $2-3 \mu \mathrm{m}$ long). Four cephalic setae (4-8 $\mu \mathrm{m}$ long); one circle of four subcephalic setae (4-8 $\mu \mathrm{m}$ long) posterior to the amphidial fovea. Amphidial fovea cryptospiral. Eight longitudinal rows of short somatic setae $(2-4 \mu \mathrm{m}$ long) running along the entire body length, continuing as four rows on the tail region. Buccal cavity narrow, elongate, with one dorsal tooth and two minute ventrosublateral teeth at the same level. Pharynx muscular with posterior bulb and plasmatic interruptions, internal lining well sclerotized. Cardia extended. Secretory-excretory system not observable. Posterior half of tail conspicuously punctuated and without striation.

Male monorchic, anterior testis to the left of the intestine. Spicule strongly curved and cephalated. Gubernaculum a narrow rod. No supplements.

Female didelphic, ovaries antidromously reflexed, both genital branches to the right of the intestine. Vulva a transversal slit.

Juveniles are similar to adults, except for the development of the reproductive system.

\section{Remarks}

Suctorians (Ciliophora) are common commensals on D. pontica. The genus Desmodora de Man, 1889 is speciose, with a complicated taxonomy. It has included several subgenera later raised to genus level 


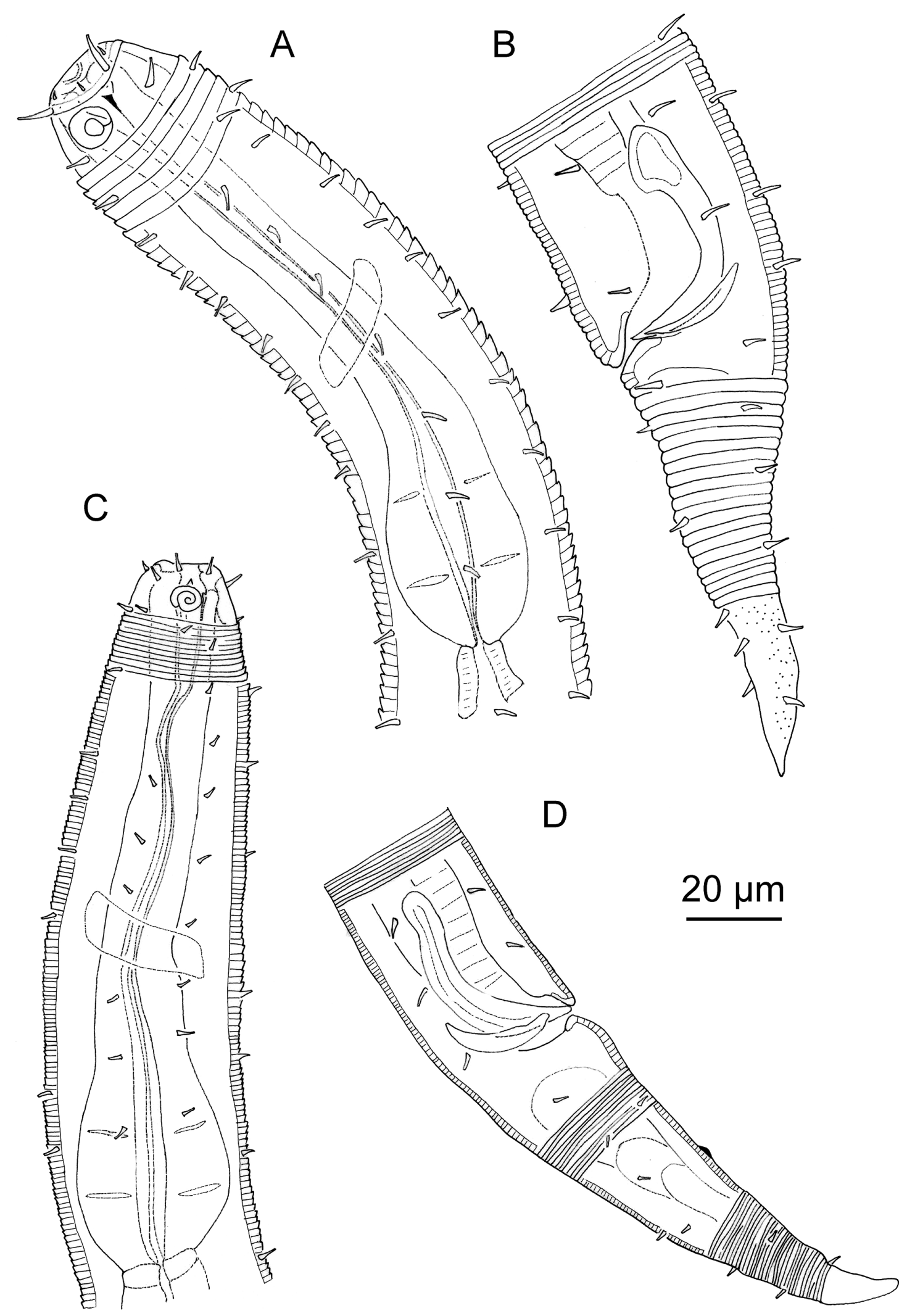

Fig. 6. A-B. Desmodora pontica Filipjev, 1922, §̂. A. Anterior region. B. Tail region, partim in surface view and copulatory apparatus. C-D. Zalonema ditlevseni (Micoletzky, 1922), §. C. Anterior region. D. Tail region and copulatory apparatus. 
by Verschelde et al. (1998) (e.g., Croconema, Pseudochromadora and Zalonema) and a plethora of bad descriptions and doubtful species. The most comprehensive study about Desmodora has been made by Verschelde et al. (1998) and an outdated dichotomous key was provided by Wieser (1954). Our specimens resemble the descriptions of D. pontica by Schuurmans Stekhoven (1950) and Gerlach (1952). The female specimen depicted and described by Boucher (1975) as $D$. pontica differs in two important features: outer labial sensilla are considerable longer (i.e., as long as the cephalic setae) and the posterior border of the head capsule reaches the first cuticle annuli. Based on our material, males seem to have amphidial fovea well in the central part of the head capsule (i.e., no contact with the striation) and juveniles and females tend to have amphidial fovea posterior on the capsule (i.e., touching the first annuli).
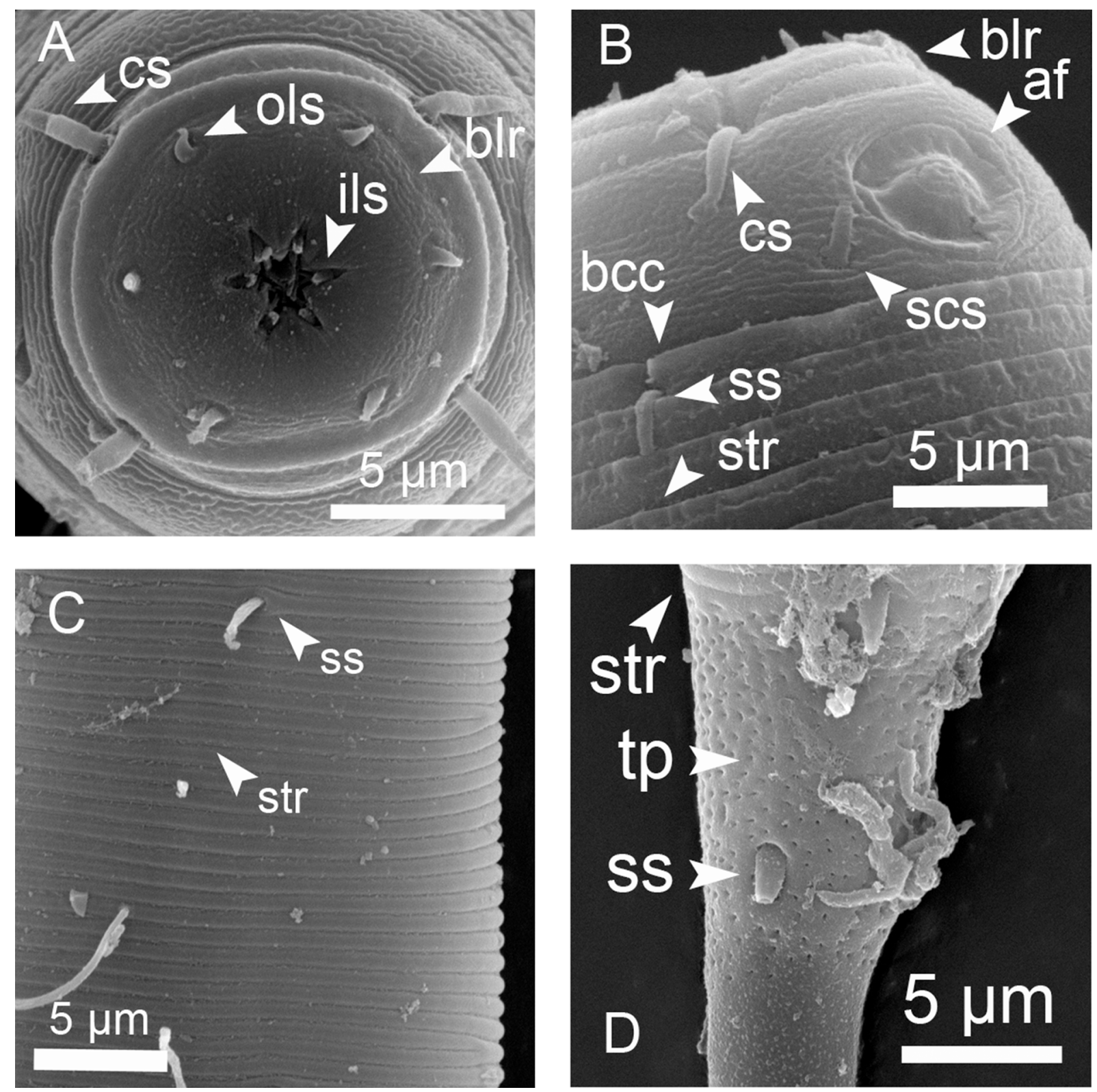

Fig. 7. Desmodora pontica Filipjev, 1922, SEM microphotographs of $\lesssim$ specimen 1 (A \& C) and specimen 2 (B \& D). A. En face view. B. Head, oblique lateral view C. Cuticle striation at mid-body region. D. Part of tail tip. 
Genus Zalonema Cobb, 1920

Zalonema ditlevseni (Micoletzky, 1922)

Figs $6 \mathrm{C}-\mathrm{D}, 8$, Table 1

Heterodesmodora ditlevseni Micoletzky, 1922: 89.

Desmodora ocellata Wieser, 1954: 172.

Desmodora (Zalonema) ditlevseni-Gerlach 1963: 92.
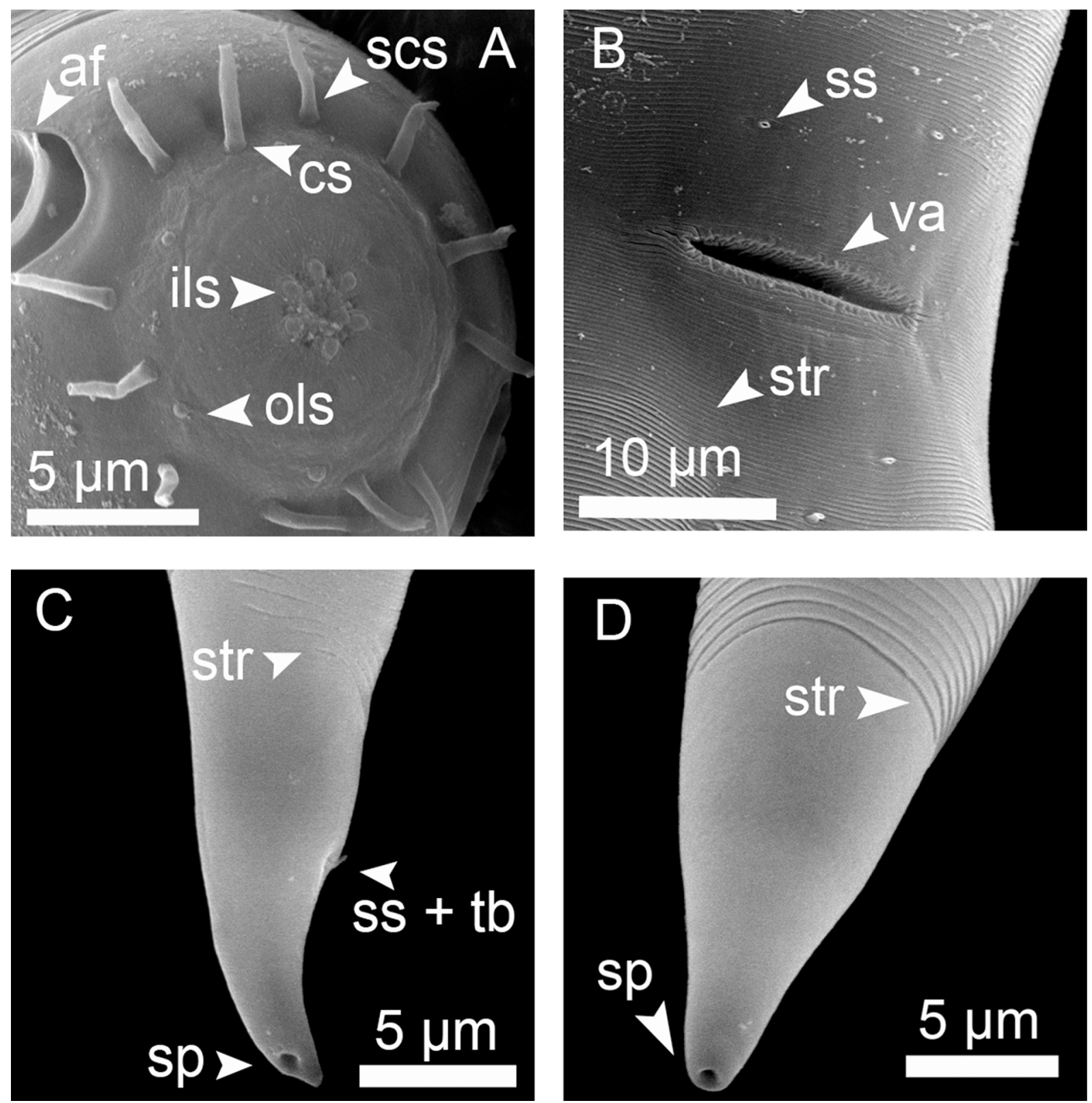

Fig. 8. Zalonema ditlevseni (Micoletzky, 1922), SEM microphotographs of $\widehat{\partial}$ (C) and $\uparrow$ (A, B \& D). A. Head in oblique en face view. B. Vulva region. C. Tail tip of $\widehat{\partial}$, subterminal opening of caudal glands. D. Tail tip of $q$. 


\section{Material examined}

$10 \widehat{\partial} \widehat{\partial}, 10$ 우 and 10 juveniles, deposited in the nematode collection at Centro de Investigaciones Marinas, Universidad de La Habana, CUBA.

\section{Description}

Cuticle coarsely striated in anterior body region (annuli $\sim 0.6-0.8 \mu \mathrm{m}$ width) but narrower at mid-body (annuli $\sim 0.5 \mu \mathrm{m}$ ). Head capsule well-developed. Inner and outer labial sensilla setiform papillae. Four cephalic sensilla (4-6 $\mu \mathrm{m}$ long) and eight subcephalic setae (4-6 $\mu \mathrm{m}$ long) almost at the same level on the head capsule. Amphidial fovea spiral with 2.0-2.5 turns. Eight longitudinal rows of short somatic setae $(\sim 1-3 \mu \mathrm{m}$ long), reduced to six rows at mid body and four rows in the posterior region. Buccal cavity with 12 cheilorhabdia, a strong dorsal tooth and two smaller ventrosublateral teeth. Pharynx muscular with posterior bulb and plasmatic interruptions, internal lining conspicuous and well-sclerotized. Cardia relatively small. Secretory-excretory system not observable. Tail conical, showing sexual dimorphism i.e., markedly bent in males and with two short subterminal setae in the tip, while more regularly conical and without subterminal setae in female.

Male monorchic, anterior testis to the right of the intestine. Spicules wide, curved, weakly cephalated. Gubernaculum a narrow rod. One or two small post-cloacal supplements in form of pits.

Female didelphic, ovaries antidromously reflexed, both genital branches to the left of intestine. Vulva a narrow transversal aperture.

Juveniles are similar to adults, except for the development of the reproductive system.

\section{Remarks}

There exist only a few detailed descriptions of $Z$. ditlevseni despite the high number of junior synonymies for this species. The body size of the single male specimen described by Gerlach (1964) lies within the range of the Cuban specimens (males: $1590 \mu \mathrm{m}$ vs $847-2022 \mu \mathrm{m}$ ); however, the single female specimen described by Schuurmans Stekhoven (1950) is slightly outside the higher range for the Cuban specimens (female: $1420 \mu \mathrm{m}$ vs $898-1380$ ). The relatively wide range of morphological variation in the body length of the species possibly masks a complex of cryptic species.

Subfamily Spiriniinae Gerlach \& Murphy, 1965

\section{Type genus}

Spirinia Gerlach, 1963 (syn. Spira Bastian, 1865: 159).

Diagnosis [emended from Decraemer \& Smol (2006)]

Body cuticle finely striated (except the genera Echinodesmodora Blome, 1982, Spirodesma and Stygodesmodora Blome, 1982). Head capsule absent (i.e., cuticle not strongly thickened) and without demarcation between labial and cephalic regions. Amphidial fovea spiral located lateral and anterior on the body, its posterior border partially or completely surrounded by cuticle striations. Buccal cavity rather small, from minute to medium-sized with dorsal tooth, two smaller ventrosublateral teeth maybe present or absent.

The main modification to the diagnosis in Decraemer \& Smol (2006) is the inclusion of coarse cuticle as exception in order to accommodate the transferred genera Echinodesmodora, Spirodesma and Stygodesmodora. We also acknowledge the absence of a head capsule. 
Genus Chromaspirina Filipjev, 1918

Chromaspirina inaurita Wieser \& Hopper, 1967

Figs 9A-B, 10, Table 2

Chromaspirina inaurita Wieser \& Hopper, 1967: 273.

\section{Material examined}

$3 \hat{\partial} \hat{\partial}, 5$ 우 and 8 juveniles, deposited in the nematode collection at Centro de Investigaciones Marinas, Universidad de La Habana, CUBA.

\section{Description}

Cuticle faintly and homogeneously striated (annuli $0.8-1 \mu \mathrm{m}$ width). Inner labial setae papilliform. Six outer labial sensilla short setiform $(\sim 1-3 \mu \mathrm{m}$ long), more or less at the same level of the four cephalic sensilla $(\sim 8-10 \mu \mathrm{m}$ long$)$ and two additional setae, one ventral and one dorsal. Amphidial fovea cryptospiral located far forward in the head, only the posterior border contacts the first cuticle annuli. Eight longitudinal rows of somatic setae running along the whole body, the most anterior longer $(6-8 \mu \mathrm{m})$ than the others $(\sim 1-3 \mu \mathrm{m})$. Buccal cavity with three small teeth, one dorsal and two ventrosublateral. Pharynx muscular with posterior bulb. Cardia extended longitudinally. Secretory-excretory system not observable. Tail conical, final portion without striation and surface smooth.

Male monorchic, anterior testis to the left of the intestine, no precloacal supplements, three postcloacal supplements like papillae (sometimes a fourth posterior smaller one). Spicules curved and slightly cephalated. Gubernaculum a simple rod with proximal end slightly widened.

Female didelphic, ovaries antidromously reflexed, both genital branches to the left of the intestine. Vulva a transversal slit.

Juveniles are similar to adults, except for the development of the reproductive system.

\section{Remarks}

Maria et al. (2009) made a revision of Chromaspirina Filipjev, 1918 and provided an illustrated key to the species. The morphology of the measured specimens closely resembles the type species described by Wieser \& Hopper (1967) from Florida. However, two important differences occurred: (1) Florida specimens were smaller than the ones from Cuba (1180-1350 $\mu \mathrm{m}$ vs 2110-2592 $\mu \mathrm{m})$ and (2) there was no evidence of sexual dimorphism in the shape and size of the amphidial fovea. The adaptation of the species to local environments seems to be the most plausible explanation for this phenotypic plasticity, but existence of a complex of cryptic species is also possible.

Genus Paradesmodora Schuurmans Stekhoven, 1942

Paradesmodora immersa Wieser, 1954

Fig. 9C-D, Table 2

Paradesmodora immersa Wieser, 1954: 39.

\section{Material examined}

$2 \widehat{\partial} \hat{\sigma}$ and 4 juveniles, deposited in the nematode collection at Centro de Investigaciones Marinas, Universidad de La Habana, CUBA. 


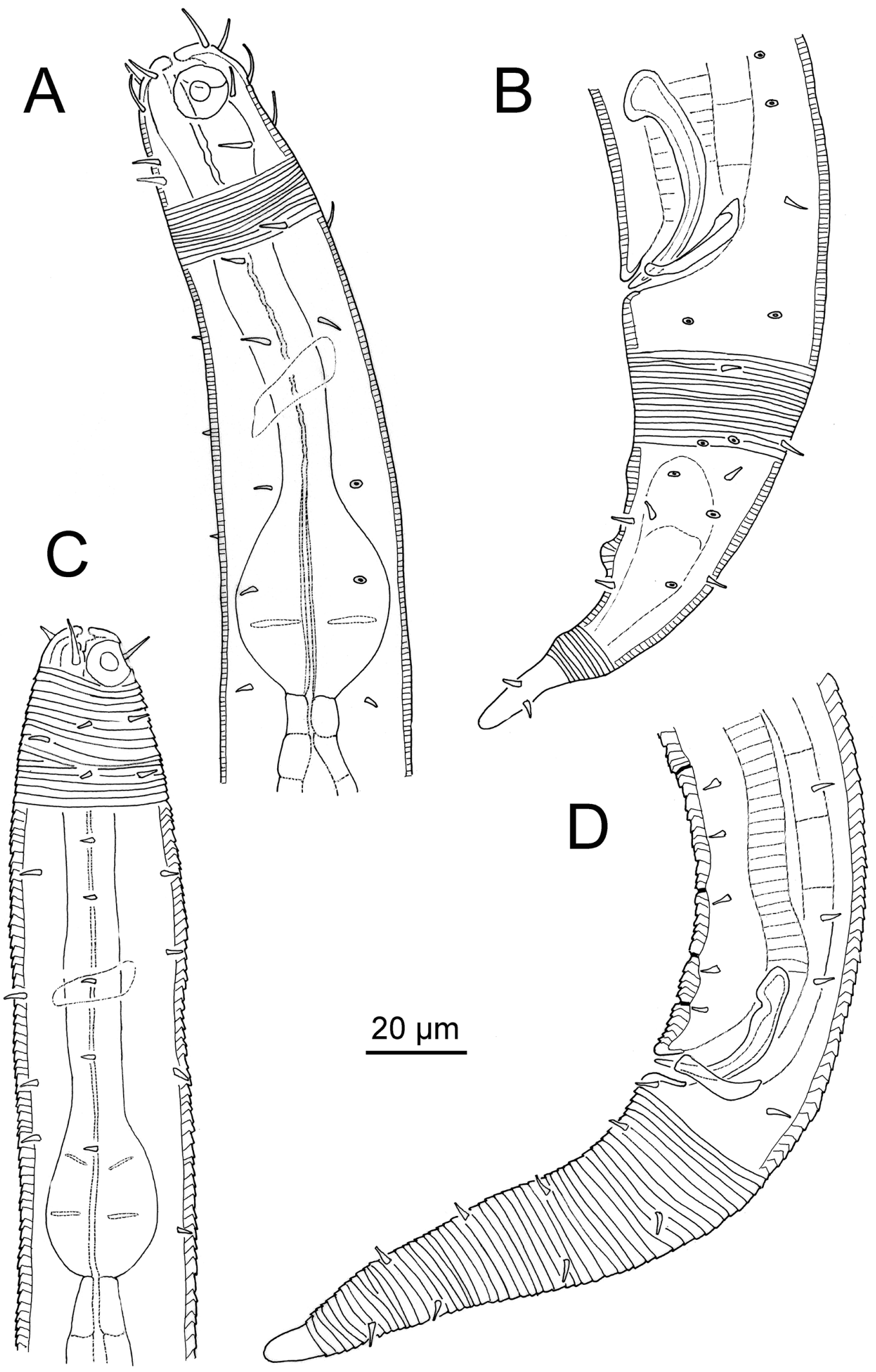

Fig. 9. A-B. Chromaspirina inaurita Wieser \& Hopper, 1967, §̂. A. Anterior region. B. Tail region and copulatory apparatus. C-D. Paradesmodora immersa Wieser, 1954, ô. C. Anterior region. D. Tail region and copulatory apparatus. 


\section{Description}

Cuticle coarsely striated (annuli $\sim 1 \mu \mathrm{m}$ width). Inner and outer labial sensilla not observable. Four cephalic sensilla setiform $(\sim 4 \mu \mathrm{m}$ long) at anterior level of amphidial fovea, no subcephalic setae. Amphidial fovea cryptospiral located far forward on the head. Six longitudinal rows of short somatic setae $(\sim 1-3 \mu \mathrm{m}$ long) running along anterior and mid body region; they become in four rows on the posterior region. Buccal cavity medium-sized, one dorsal tooth, two ventrosublateral smaller teeth. Pharynx muscular with posterior bulb and plasmatic interruptions. Cardia extended. Secretory-excretory system not observable. Tail conical, last portion without striation, short setae present, spinneret present.

Male monorchic, anterior testis to the left of intestine. Spicules curved and slightly cephalated. Gubernaculum a narrow rod. Precloacal supplements (12-16) like small marks in the ventral cuticle.

Juveniles are similar to adults, except for the development of the reproductive system.
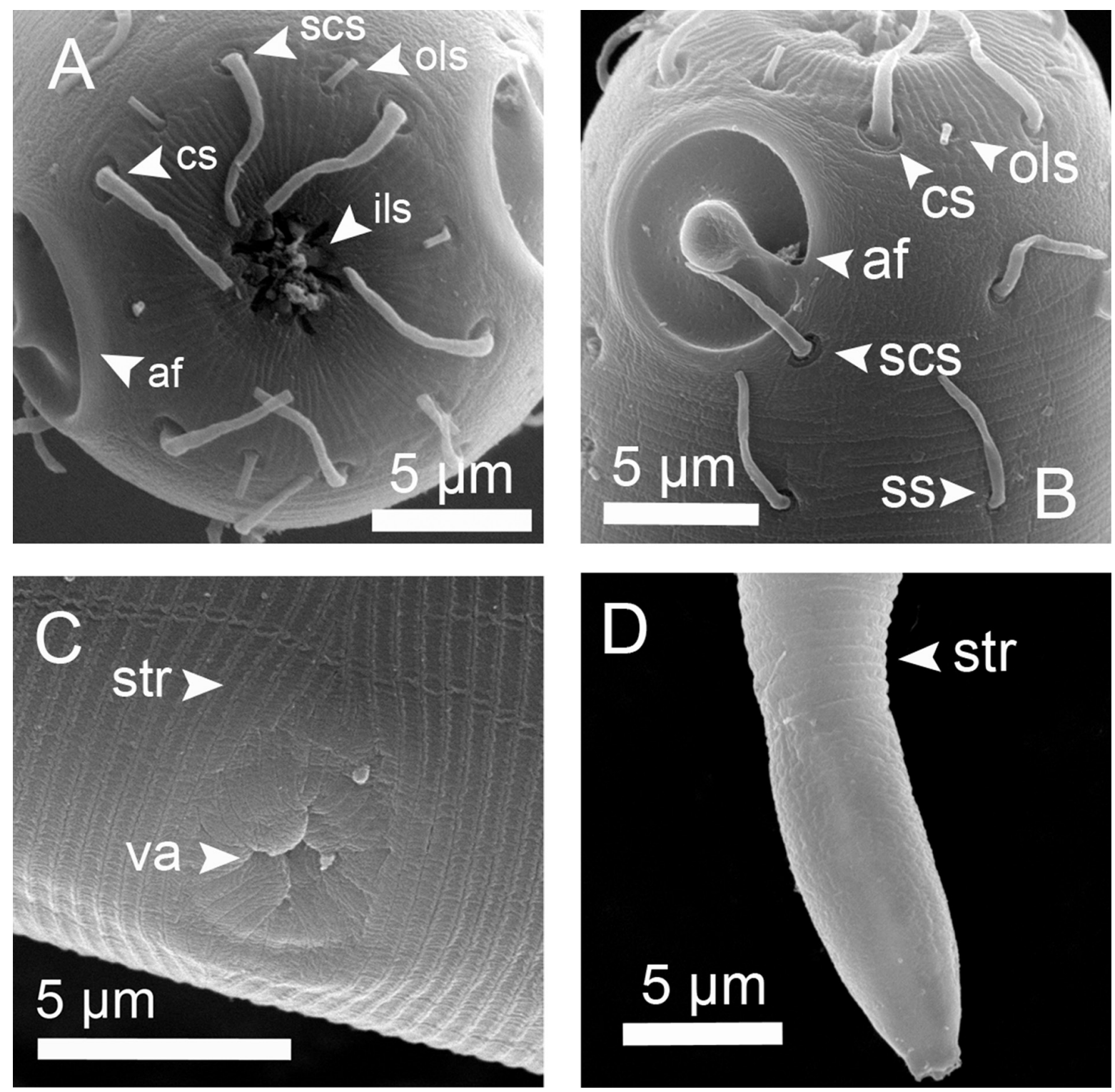

Fig. 10. Chromaspirina inaurita Wieser \& Hopper, 1967, SEM microphotographs of +. A. Labial region, en face view. B. Head, oblique lateral view. C. Vulva region. D. Tail tip. 


\section{Remarks}

Measured specimens resemble the holotype of P. immersa described by Wieser (1954); unfortunately, there are no other records of this species. Specimens in Wieser (1954) were larger (male: $2200 \mu \mathrm{m}$; female: $2410 \mu \mathrm{m}$ ) than ours (males: 1424-2081 $\mu \mathrm{m}$, no females measured). The number of precloacal supplements reported by this author is 15 and this fits the range of specimens in our study (12-16).

Paradesmodora toreutes has been collected from a nearby region (Florida). It can be clearly differentiated from P. immersa by: (1) the cuticular differentiation of the head (plates surrounding the amphids vs no plates); (2) the proximal end of spicule with a notch in the capitulum vs rounded shape); (3) the number of precloacal supplements (10 vs 15$)$; and (4) longer tail in males $\left(\mathrm{c}^{\prime}=6 \mathrm{vs} \mathrm{c}^{\prime}=3\right)$.

Genus Spirinia Gerlach, 1963

\section{Spirinia parasitifera (Bastian, 1865)}

Figs 11, 12, Table 2

Spira parasitifera Bastian, 1865: 159.

Spiliphera oxycephala Bütschli, 1874: 47.

Spirinia nidrosiensis Allgén, 1933: 60.
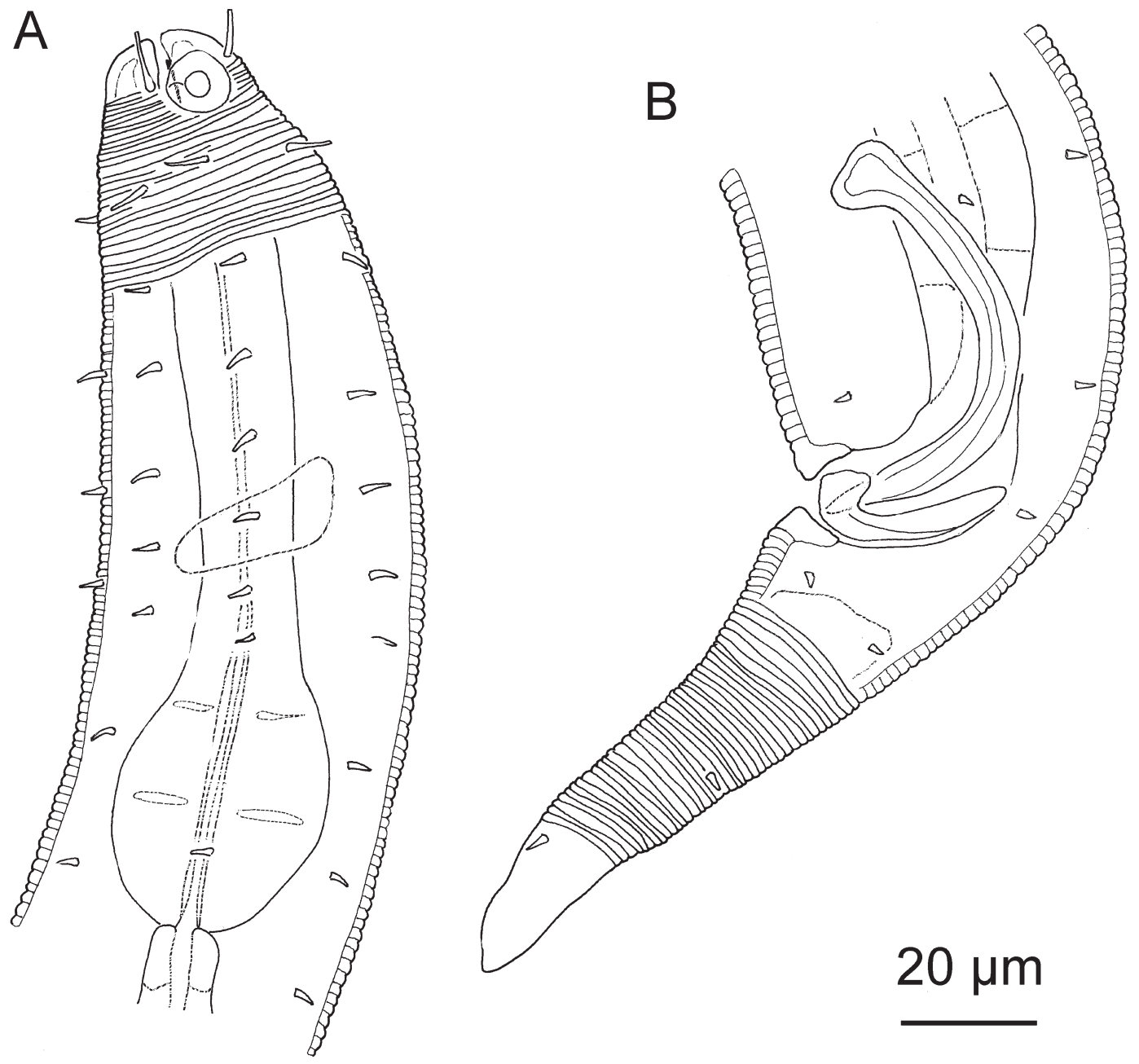

Fig. 11. Spirinia parasitifera (Bastian, 1865). A. Anterior region of a juvenile. B. Posterior region of $\widehat{o}$. 
Table 2. Mean (range) of morphological measures for three nematode species of the subfamily Spiriniinae from the Punta Francés coral reef, Cuba. $\mathrm{N}=$ number of specimens, $\mathrm{J}=$ juvenile. For each variable the first row corresponds to males, the second to females and the third to juveniles. Abbreviations: a.b.d. $=$ anal body diameter; Amp. Fovea c.b.d. = relation of amphidial fovea diameter to corresponding body diameter; de Man ratios are the relation of body length to body diameter (a), to pharynx length (b) and to tail length (c) respectively; $\mathrm{c}^{\prime}=$ relation of tail length to anal body diameter, $\mathrm{V} \%=$ distance (relative to body length) of vulva to anterior end.

\begin{tabular}{|c|c|c|c|}
\hline Species/Variable & Chromaspirina inaurita & Paradesmodora immersa & Spirinia parasitifera \\
\hline $\mathbf{N}$ & $3 \widehat{\partial} \delta^{\lambda}, 5$ q,$++ 8 \mathrm{~J}$ & $2 \hat{\partial}, 4 \mathrm{~J}$ & 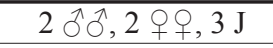 \\
\hline $\begin{array}{l}\text { Body length } \\
(\mu \mathrm{m})\end{array}$ & $\begin{array}{c}2380(2110-2592) \\
2393(1825-2701) \\
1226(694-1744)\end{array}$ & $\begin{array}{c}1753(1424-2081) \\
- \\
914(277-1635)\end{array}$ & $\begin{array}{l}2712(1854-3570) \\
3300(2803-3796) \\
1151(1007-1307)\end{array}$ \\
\hline de Man ratio a & $\begin{array}{l}59(59-60) \\
53(49-55) \\
39(24-50) \\
\end{array}$ & $\begin{array}{c}47(37-58) \\
- \\
30(13-61) \\
\end{array}$ & $\begin{array}{l}39(29-49) \\
43(41-45) \\
28(27-30) \\
\end{array}$ \\
\hline de Man ratio b & $\begin{array}{c}19(17-20) \\
20(18-22) \\
12(8-16) \\
\end{array}$ & $\begin{array}{c}14(11-18) \\
- \\
9(5-13) \\
\end{array}$ & $\begin{array}{c}21(18-24) \\
23(21-26) \\
9(8-11) \\
\end{array}$ \\
\hline de Man ratio c & $\begin{array}{l}23(23-24) \\
30(21-34) \\
17(12-20)\end{array}$ & $\begin{array}{c}24(22-27) \\
- \\
12(5-22)\end{array}$ & $\begin{array}{l}25(21-29) \\
25(22-28) \\
18(17-19)\end{array}$ \\
\hline $\begin{array}{l}\text { Amp. fovea c.b.d. } \\
(\%)\end{array}$ & $\begin{array}{l}38(31-43) \\
36(30-52) \\
29(26-33)\end{array}$ & $\begin{array}{c}54(48-59) \\
- \\
41(38-47) \\
\end{array}$ & $\begin{array}{l}36(33-38) \\
37(36-38) \\
42(35-48) \\
\end{array}$ \\
\hline $\begin{array}{l}\text { Pharynx length } \\
(\mu \mathrm{m})\end{array}$ & $\begin{array}{c}124(121-129) \\
120(100-129) \\
99(81-119) \\
\end{array}$ & $\begin{array}{c}124(119-128) \\
- \\
96(53-130) \\
\end{array}$ & $\begin{array}{l}127(102-151) \\
142(136-148) \\
124(122-125) \\
\end{array}$ \\
\hline $\begin{array}{l}\text { Maximum body ø } \\
(\mu \mathrm{m})\end{array}$ & $\begin{array}{l}40(36-43) \\
45(33-45) \\
32(20-43) \\
\end{array}$ & $\begin{array}{c}38(36-39) \\
- \\
30(22-44) \\
\end{array}$ & $\begin{array}{l}69(65-73) \\
77(62-92) \\
41(34-46) \\
\end{array}$ \\
\hline $\begin{array}{l}\text { Tail length } \\
(\mu \mathrm{m})\end{array}$ & $\begin{array}{c}101(92-109) \\
81(69-89) \\
78(60-96) \\
\end{array}$ & $\begin{array}{c}75(52-97) \\
- \\
71(51-119) \\
\end{array}$ & $\begin{array}{c}106(88-123) \\
133(130-137) \\
63(60-68) \\
\end{array}$ \\
\hline Tail length $\mathrm{c}^{\prime}$ & $\begin{array}{l}2.9(2.7-3.0) \\
2.6(2.2-3.6) \\
2.7(2.1-3.0)\end{array}$ & $\begin{array}{c}2.6(1.9-3.3) \\
- \\
3.4(2.0-4.3) \\
\end{array}$ & $\begin{array}{l}2.2(2.1-2.2) \\
2.7(2.6-2.8) \\
2.2(2.0-2.3)\end{array}$ \\
\hline V\% & $55(48-67)$ & - & 51 \\
\hline $\begin{array}{l}\text { Spiculum length } \\
(\mu \mathrm{m})\end{array}$ & $51(50-52)$ & $45(34-55)$ & $81(72-89)$ \\
\hline $\begin{array}{l}\text { Gubernaculum length } \\
(\mu \mathrm{m})\end{array}$ & $24(22-27)$ & $19(18-20)$ & $28(25-31)$ \\
\hline
\end{tabular}

\section{Material examined}

$2 \hat{\jmath} \partial^{\lambda}, 2$ 우 $ᄋ$ and 3 juveniles, deposited in the nematode collection at Centro de Investigaciones Marinas, Universidad de La Habana, CUBA.

\section{Description}

Cuticle finely striated in the anterior region (annuli $\sim 1 \mu \mathrm{m}$ width) but even narrower in the mid-body and tail region. Inner and outer labial sensilla papilliform (1-2 $\mu \mathrm{m}$ long), four cephalic setae (7-10 $\mu \mathrm{m}$ long) at level of amphidial fovea. Amphidial fovea cryptospiral located forward in the head ( $<6 \mu \mathrm{m}$ from apex). Eight longitudinal rows of somatic setae decreasing in length from the cervical region (7-10 $\mu \mathrm{m}$ long) to papillae at mid-body and tail region. Pharynx muscular with posterior bulb and internal lining sclerotized. Cardia inconspicuous. Secretory-excretory system not observable. Tail conical, last portion without striations. 
Male monorchic; spicules strongly bent, with capitulum, gubernaculum a bent rod dorsally oriented; without precloacal supplements.

Female didelphic, amphidelphic with reflexed ovaries, vulva a transversal aperture.

Juveniles are similar to adults, except for the development of the reproductive system.

\section{Remarks}

S. parasitifera is a cosmopolitan species recorded from several habitats and biogeographical regions. Coles (1987) noted that the main differences among populations from widely divergent coasts (England, Canada and USA) were the shape of the proximal end of the spicules and the body size. He reported
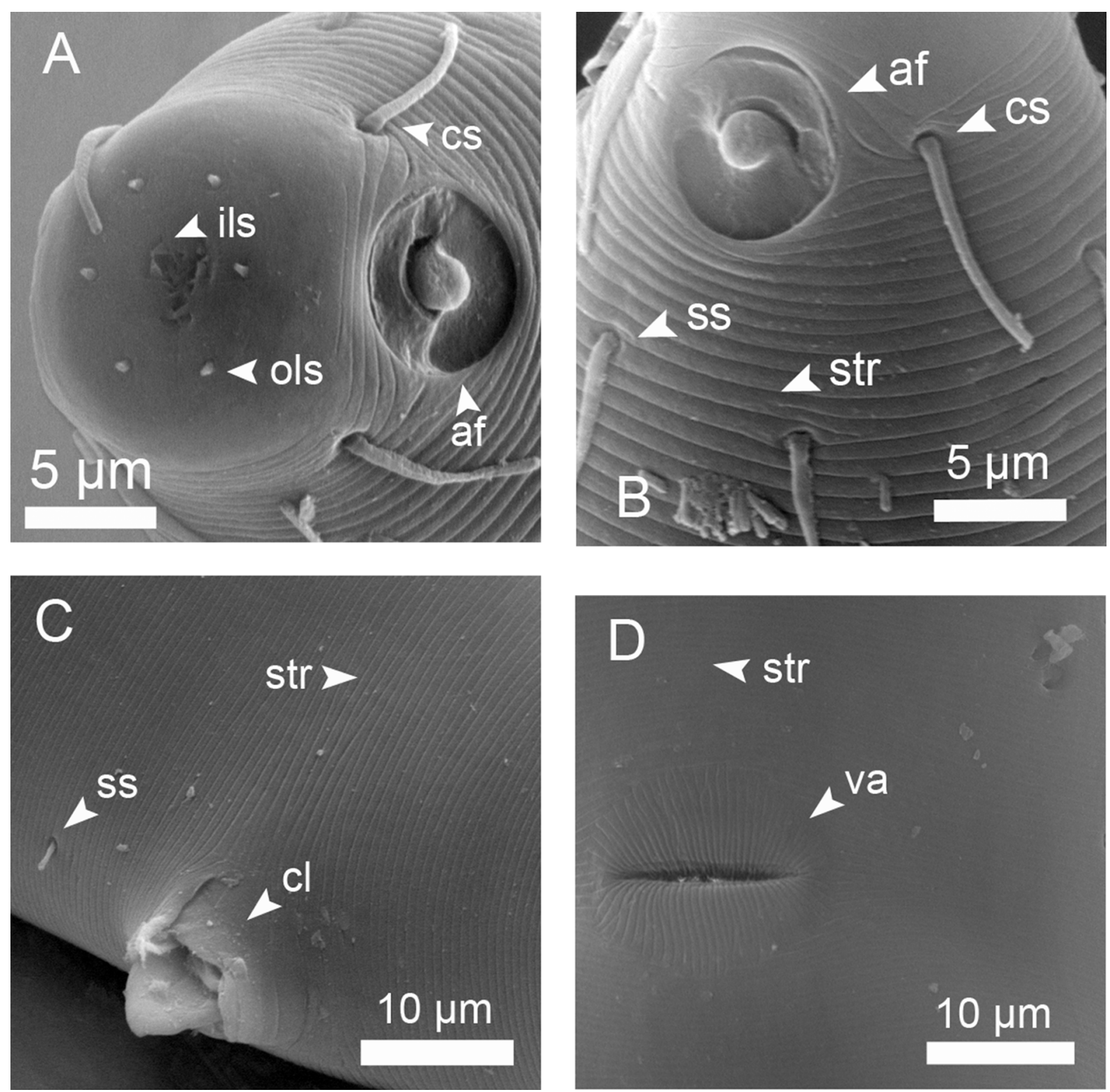

Fig. 12. Spirinia parasitifera (Bastian, 1865), SEM microphotographs of $\widehat{\partial}(\mathrm{A}, \mathrm{B} \& \mathrm{C})$ and $\varnothing$ (D). A. Head in frontal view. B. Head in lateral view. C. Anal region with portion of protruding spicule. D. Vulva. 
that specimens from warmer waters (Florida) had smaller body size (males: 1650-2150 $\mu \mathrm{m}$; females: 1650-1910 $\mu \mathrm{m}$ ) compared to specimens from temperate waters (males: 2000-3300 $\mu \mathrm{m}$; females: 2020-3180 $\mu \mathrm{m}$ ). However, our specimens from a tropical area (Caribbean Sea) had body size closer to those from colder waters (males: 1854-3570 $\mu \mathrm{m}$; females: 2803-3796 $\mu \mathrm{m}$ ). Therefore, a negative relationship between water temperature and body size is not plausible for this species. For some species we studied in this paper this negative relationships is supported (e.g., Acanthopharynx denticulatus, Paradesmodora immersa) but not for other (e.g., Spirinia parasitifera, Chromaspirina inaurita). The considerable geographic variation in the morphology of $S$. parasitifera suggests the existence of cryptic species within this nominal species.

Another rare sympatric species, belonging to the genus Spirinia, has been recorded in our samples with only two specimens. The species was characterized by the small body size (male: $686 \mu \mathrm{m}$; female: $684 \mu \mathrm{m}$ ) and two kinds of somatic setae (long: $28-35 \mu \mathrm{m}$ and short $5-8 \mu \mathrm{m}$ ). It is closer to $S$. gnaigeri Ott, 1977 (Ott 1977: 134); however, body size of type specimens in Ott (1972) is larger (males: 860$913 \mu \mathrm{m}$; females: 836-955 $\mu \mathrm{m}$ ) and the length of both somatic setae shorter (long setae: $20-22 \mu \mathrm{m}$; short setae: $4-5 \mu \mathrm{m})$. However, more specimens should be examined in order to evaluate if this is really a new species of Spirinia.

\section{Taxa inquirendae}

The subfamilies Desmodorinae and Spiriniinae have 11 and 14 valid genera, respectively (after the change we propose below). Within the subfamilies, some species-rich genera have a reasonably good taxonomic account such as Croconema (12 species revised in Verschelde et al. 2006), Desmodora (27 species revised in Verschelde et al. 1998) and Chromaspirina (20 species revised in Maria et al. 2009). However, many unidentified species are present in collections of speciose genera, such as Acanthopharynx, Croconema, Onyx and Perspiria (Venekey et al. 2010). For other genera, only single species have been described (e.g., Psammonema Verschelde \& Vincx, 1995; Parallelocoilas Boucher, 1975). In some old publications, the descriptions did not cover the needed diagnostic characters and for these genera, further taxonomic identification was not possible. On this basis we propose Alaimonema Cobb, 1920 and Sigmophoranema (Cobb, 1933) as genera inquirendae.

Alaimonema Cobb, 1920 was classified within Spiriniinae by Lorenzen (1994) based on the presence of posterior pharyngeal bulb, the single anterior testis and the structure of precloacal supplements; but for the first and third features no drawings were provided by Cobb (1920). The original description of the genus does not provide information on essential characters for a proper evaluation. Diagnostic features that are missed in the description are: (1) cuticle striation in respect to the amphidial fovea, (2) shape of the pharynx and spicules, (3) number, shape and position of the precloacal supplements and (4) tail shape. This monospecific genus would be part of the Spirinia or even the closely related Perspiria. Therefore, we classify Alaimonema as genus inquirenda and the species A. multicinctum Cobb, 1920 as species inquirenda.

Sigmophoranema (Cobb, 1933) was proposed after Nathan A. Cobb's death by M. V. Cobb (1933) based on N.A. Cobb's manuscripts with the original name of Sigmophora. No drawings were presented neither of the genus nor of the type species Sigmophora rufum Cobb, 1933. Hope and Murphy (1972) proposed a new name (Sigmophoranema) since the original genus name was already occupied by a hymenopteran. We declare Sigmophoranema as genus inquirenda and S. rufum as species inquirenda based on the absence of any drawing of the type species and on the relatively poor descriptions of the described specimens. We transfer the species S. brevispiculatum Inglis, 1963 (Inglis 1963: 537), S. litorale Schulz, 1939 (Schulz 1939: 119) and S. monstrosum Gerlach, 1956 (Gerlach 1956: 431) to the genus Onyx Cobb, 1891 as O. brevispiculatum comb. nov., O. litorale comb. nov. and O. monstrosum comb. nov., 
respectively. The latter three species bear the two diagnostic features of the genus Onyx: large spear-like dorsal tooth and s-shaped precloacal supplements.

Other two already proposed genera inquirendae within Desmodoridae were Amphispira Cobb, 1920 and Metadesmodora Schuurmans Stekhoven, 1942. They were proposed by Verschelde et al. (2006) and we agree with them because their types species were poorly described from single female and juvenile specimens respectively.

\section{Taxa with new classification}

Paradesmodora Schuurmans Stekhoven, 1950 with type species $P$. cephalata Schuurmans Stekhoven, 1950 currently contains six more species: P. campbelli (Allgén, 1932); P. immersa Wieser, 1954; P. punctata Gerlach, 1963; P. sinuosa Ott, 1972; P. supplementatis Inglis, 1968 (Inglis 1968: 58); and P. toreutes Wieser \& Hopper, 1967. The latter authors considered the type species $P$. cephalata as species inquirenda because it was described from a juvenile female only. This genus was formerly included in the Desmodorinae by Decraemer \& Smol (2006) and by Verschelde et al. (2006). We transfer Paradesmodora to the Spiriniinae based on three diagnostic features: (1) absence or poorly developed head capsule (i.e., cuticle not thickened compared to body cuticle) without demarcation between labial and cephalic region; (2) fine to medium striation of the body cuticle; and (3) amphidial fovea partially surrounded by cuticle striations.

In P. sinuosa Ott, 1972, however, the head capsule is more or less delimited by the smooth cuticle; but, we do not consider that it is "well-developed" as stated by Ott (1972). The amphidial fovea, due to its posterior position, is partially surrounded by the anterior most body annules. Therefore, taking into account these two features, we still consider P. sinuosa to belong to the genus Paradesmodora.

Wieser \& Hopper (1967) characterized their new species P. toreutes by the cuticular differentiations of the head that they describe as "head very much enlarged and forming plates which surround the anterior portions of the amphids". The illustration of a male and LM microphotographs of the holotype show a protruding lip region, a subdivided smooth head capsule by an anterior suture, and the presence of an enlarged head capsule with cuticular plates. These features are different from the Spiriniinae. Therefore, we consider that $P$. toreutes Wieser \& Hopper, 1967 fits neither in the genus Paradesmodora nor in the subfamily Spiriniinae. Thus, it is transferred, within the subfamily Desmodorinae, to the genus Acanthopharyngoides Chitwood, 1936 as A. toreutes comb. nov. A. toreutes comb. nov. fits within Acanthopharyngoides because of the unique combination of body size, shape of the spicule (hookshaped), number of pre-cloacal supplements (10) and the posterior border of the fovea surrounded by cuticle annuli. This genus has by now seven species: A. bidentatus Jensen, 1985 (Jensen 1985: 256); A. chitwoodi Wieser, 1954; A. duplex Gerlach, 1963; A. quintus Riemann \& Schrage, 1977 (Riemann \& Schrage 1977): 49; A. scleratus Gerlach, 1963; A. thyrrhenicus Wieser, 1954 and A. toreutes (Wieser \& Hopper, 1967) comb. nov.

Echinodesmodora Blome, 1982 is transferred from the subfamily Desmodorinae to the Spiriniinae because the diagnoses of both subfamilies changed. The characters that support the membership to the Spiriniinae are: (1) the absence of the head capsule; (2) no demarcation between labial and cephalic regions; (3) the amphidial fovea is surrounded by cuticle striations; and (4) the presence of one dorsal tooth and two ventrosublateral teeth. The coarse striation of the cuticle suggests resemblance with the Desmodorinae, but this character within this subfamily is variable (e.g., coarse striation in Croconema, fine striation in Acanthopharyngoides) and does not support membership of the Desmodorinae.

Stygodesmodora Blome, 1982 resembles Echinodesmodora, but is mainly differentiated by the amphidial fovea located on a basal plate and the absence of subcephalic setae present in Echinodesmodora. 
Stygodesmodora also possesses diagnostic characters of the Spiriniinae such as absence of a head capsule, no demarcation between labial and cephalic regions, amphidial fovea surrounded by cuticle striation and one dorsal tooth and two smaller ventrosublateral teeth.

A new monospecific genus Onepunema Leduc \& Verschelde, 2013 has recently been introduced and classified within the Desmodorinae, based mainly on the presence of a head capsule (Leduc \& Verschelde 2013). The new genus is also characterized by two testes, a character that disagrees with the single holapomorphy (monorchic males) of the superfamily Desmodoroidea (Lorenzen 1994). The presence of diorchic males is characteristic for the superfamily Microlaimoidea Micoletzky, 1922. Within the Microlaimoidea, didelphic females and coarsely annulated body cuticle are typical features of the Microlaimidae Micoletzky, 1922. Further, the presence of reflexed ovaries, pores in the cuticle connected to epidermal gland cells and the absence of somatic setae suggest a relationship with Bolbolaimus Cobb, 1920, Calomicrolaimus Lorenzen, 1976 and Microlaimus de Man, 1880. The taxonomy of these three genera is not completely understood according to Platt \& Warwick (1988) and Decraemer \& Smol (2006). Further descriptions of new species and genus have been done (e.g., Muthumbi \& Vincx 1999; Armenteros et al. 2010) but the relationships among the genera remain unclear. In conclusion, we refrain from including Onepunema within the family Desmodoridae and regard it as taxa incertae sedis.

\section{List of valid genera of Desmodorinae (11)}

Acanthopharyngoides Chitwood, 1936; Acanthopharynx Marion, 1870; Bolbonema Cobb, 1920; Croconema Cobb, 1920; Desmodora de Man, 1889; Desmodorella Cobb, 1933; Psammonema Verschelde \& Vincx, 1995; Pseudochromadora Daday, 1899; Pseudodesmodora Boucher, 1975; Sibayinema Verschelde et al., 2006; Zalonema Cobb, 1920.

The keys for genera of the Desmodorinae provided in Decraemer \& Smol (2006) and Verschelde et al. (2006) are still useful since they start with the three genera we transferred and which can be easily omitted and they did not include the recent genus Onepunema.

\section{List of valid genera of Spiriniinae (14)}

Chromadoropsis Filipjev, 1918; Chromaspirina Filipjev, 1918; Echinodesmodora Blome, 1982; Metachromadora Filipjev, 1918; Onyx Cobb, 1891; Papillonema Verschelde, Muthumbi \& Vincx, 1995; Paradesmodora Schuurmans Stekhoven, 1942; Parallelocoilas Boucher, 1975; Perspiria (Wieser \& Hopper, 1967); Polysigma Cobb, 1920; Pseudometachromadora Timm, 1952; Spirinia Gerlach, 1963; Spirodesma Cavalcanti et al., 2009; Stygodesmodora Blome, 1982.

\section{Key to the genera of Spiriniinae}

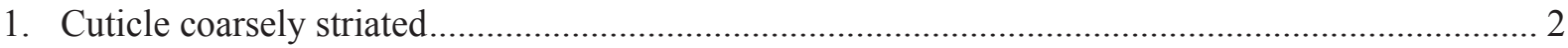

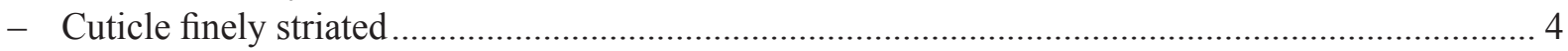

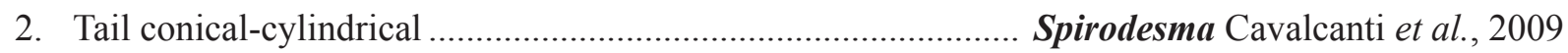

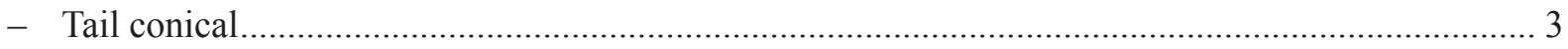

3. Amphidial fovea on a cuticular plate, somatic setae present and spines absent

- Amphidial fovea not on a cuticular plate, somatic setae and spines present

4. Buccal cavity spacious, parallel and sclerotized walls .............................................................. 5

- Buccal cavity approximately conical (of large or medium size) or minute........................................ 6 
5. Amphidial fovea multispiral, buccal armature with one dorsal tooth and no ventrosublateral teeth.. Parallelocoilas Boucher, 1975

- Amphidial fovea cryptospiral, buccal armature with one dorsal tooth and two ventrosublateral teeth. Pseudometachromadora Timm, 1952

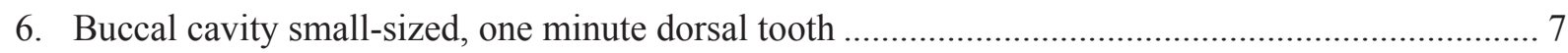

- Buccal cavity from medium to larger size, dorsal tooth large ........................................................... 8

7. Tail conical and finely striated Spirinia Gerlach, 1963

- Tail conical-cylindrical (including filiform) and coarsely striated

Perspiria (Wieser \& Hopper, 1967)

8. Single or multiple pharyngeal posterior bulb muscular enlarged and internal lining of the pharynx

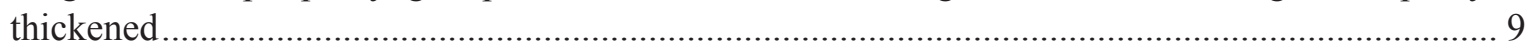

- Single pharyngeal posterior bulb rounded and internal lining of the pharynx not thickened.......... 12

9. Dorsal tooth large spear-like, precloacal supplements S-shaped. Onyx Cobb, 1891

- Dorsal tooth not spear-like, precloacal supplements not S-shaped

10. Pharynx posterior bulb barrel-shaped, buccal cavity large-sized, dorsal tooth prominent

Metachromadora Filipjev, 1918

- Pharynx posterior bulb other shaped, buccal cavity medium-sized . .11

11. Pharynx posterior bulb divided in 2-4 bulbi, outer labial sensilla setiform, subcephalic setae present, precloacal supplements as cuticular plates .

Chromadoropsis Filipjev, 1918

- Pharynx posterior bulb not divided in bulbi, outer labial sensilla papilliform, subcephalic setae absent, precloacal supplements as papillae.

Papillonema Verschelde et al., 1995

12. Precloacal supplements S-shaped

Polysigma Cobb, 1920

- Precloacal supplements with other shape or absent.

13. Subcephalic setae present

Chromaspirina Filipjev, 1918

- Subcephalic setae absent Paradesmodora Schuurmans Stekhoven, 1942

\section{Discussion}

The systematics of the family Desmodoridae has been addressed mainly from a morphological approach. However, a recent molecular analysis (Armenteros et al. in press) reports the monophyly of this family within the Nematoda. These authors suggest that Desmodorinae and Spiriniinae seem to be paraphyletic. The main limitation to address the systematics of these subfamilies are the poor representation of taxa in the phylogenetic studies. A future prospectus should include the sampling and DNA sequencing of more desmodorid genera in order to place them more firmly in a phylogenetic framework. It may result in the identification of clades that would be upgraded to the subfamily level. Until now, our proposal of the systematics for Desmodorinae and Spiriniinae is the most updated and complete for these groups. The proposed taxonomic changes lead to a more coherent grouping of the species and enhance the further assignation of sampled specimens into the groups.

The diversity of desmodorid species is high and distributed asymmetrically across the genera. There are speciose genera (e.g., Desmodora, Metachromadora and Spirinia), but other with only one or two species (e.g., Papillonema, Parallelocoilas). Coral reefs in particular seem to be very rich in desmodorid species and further research should discover new taxa in this family. 


\section{Acknowledgements}

M.A. thanks the kind support of the Invertebrate Section's staff at Royal Belgian Institute of Natural Science; especially Julien Cillis for the SEM photographs and Frank Fiers for LM photos. Quing Yu and Jon Norenburg are acknowledged for providing photographs of type material from the Canadian National Collection of Nematodes and Smithsonian National Museum of Natural History respectively. This research was funded by a 2010 Post-Doc fellowship from Belgian Science Policy to M.A. Field expeditions were funded in the framework of Wallacea Operation Cuba 2009 and 2010. The authors thank two anonymous reviewers and EJT editors Rudy Jocqué and Koen Martens who improved the manuscript with useful comments and criticisms.

\section{References}

Allgén C. 1933. Freilebende Nematoden aus dem Trondhjemsfjord. Capita Zoologica 4 (2):1-162.

Allgén C.A. 1947. West American marine nematodes (Papers from Dr. Th. Mortensen's Pacific Expedition 1914-1916, 75). Videnskabelige Meddelelser Dansk Naturhistorisk Forening 110: 65-219.

Armenteros M., Rojas-Corzo A., Ruiz-Abierno A., Derycke S., Backeljau T., Decraemer W. In press. Systematics and DNA barcoding of free-living marine nematodes with emphasis on tropical desmodorids using nuclear SSU rDNA and mitochondrial COI sequences. Nematology. http://dx.doi. org/10.1163/15685411-00002824

Armenteros M., Ruiz-Abierno A. \& Decraemer W. 2014. Taxonomy of Stilbonematinae (Nematoda: Desmodoridae): description of two new and three known species and phylogenetic relationships within the family. Zoological Journal of the Linnean Society 171 (1): 1-21. http://dx.doi.org/10.1111/zoj.12126

Armenteros M., Ruiz-Abierno A., Sosa Y. \& Pérez-García J.A. 2012. Habitat heterogeneity effects on macro- and meiofauna (especially nematodes) in Punta Francés coral reef (SW Cuban Archipelago). Revista de Investigaciones Marinas 32 (1): 50-61.

Armenteros M., Vincx M. \& Decraemer W. 2010. Guitartia tridentata n. gen., n. sp. (Monhysterida: Xyalidae) and Macrodontium gaspari n. gen., n. sp. (Chromadorida: Microlaimidae), free-living marine nematodes from the Caribbean Sea. Nematology 12 (3): 417-427. http://dx.doi.org/10.1163/13885540 $\underline{\text { 9X12559479585007 }}$

Bastian H.C. 1865. Monograph of the Anguillulidae, or Free Nematoids, Marine, Land, and Freshwater; with Descriptions of 100 New Species. Transactions of the Linnean Society of London 25 (2): 73-184. http://dx.doi.org/10.1111/j.1096-3642.1865.tb00179.x

Blome D. \& Riemann F. 1994. Sandy Beach Meiofauna of Eastern Australia (Southern Queensland and New South Wales). III.* Revision of the Nematode Genus Onyx Cobb, 1891, with a Description of Three New Species (Nematoda: Desmodoridae). Invertebrate Taxon 8 (6): 1483-1492. http://dx.doi. org/10.1071/IT9941483

Boucher G. 1975. Nématodes des sables fins infralittoraux de la Pierre Noire (Manche occidentale). I. Desmodoridae. Bulletin du Muséum national d'Histoire naturelle, 3e série Zoologie 285: 101-128.

Bütschli D. 1874. Zur Kenntnis der freilebenden Nematoden, insbesondere der des Kieler Hafens. Abhandlungen der Senckenbergischen Naturforschenden Gesellschaft 9 (3).237-292

Cobb N.A. 1920. IX. One hundred new nemas. In: Cobb N.A. Contributions to a Science of Nematology: 217-234. Williams \& Wilkins Co., Baltimore. http://dx.doi.org/10.5962/bhl.title.20608

Cobb N.A. 1933. New Nemic Genera and Species, with Taxonomic Notes. Journal of Parasitology 20 (2): 81-94. http://dx.doi.org/10.2307/3272166 
Coles J.W. 1987. Observations on the marine nematode genus Spirinia Gerlach, 1963 (Desmodoridae: Spiriniinae) with descriptions of two new species. Bulletin of the British Museum (Natural History). Zoology 53 (2): 79-101.

Decraemer W. \& Smol N. 2006. Chapter 17. Orders Chromadorida, Desmodorida and Desmoscolecida. In: Abebe E., Traunspurger W. \& Andrássy I. (eds) Freshwater nematodes: Ecology and taxonomy: 497-573. CABI Publishing, Wallingford. http://dx.doi.org/10.1079/9780851990095.0497

Dinh Tu N., Smol N., Vanreusel A. \& Vu Thanh N. 2011. Six new species of the genus Onyx Cobb, 1891 (Nematoda: Desmodoridae) from Coastal Areas in Vietnam. Russian Journal of Nematology 19 (1): 1-20.

Filipjev I.N. 1922. Sur les Nématodes libres de la mer d'Azov. Trudy Stavropol'skago Sel'skokhozyaistvennago Instituta 1 (7): 185-208.

Fonseca Cavalcanti M., Silva M.C. \& Fonsêca-Genevois V. 2009. Spirodesma magdae nov. gen. nov. sp. (Nematoda: Desmodoridae) from the Brazilian deep sea (Campos Basin, Rio de Janeiro, Brazil). Zootaxa 2096: 109-118.

Furstenberg J.P. \& Vincx M. 1988. Three new Chromadoropsis species (Nematoda, Desmodoridae) from Southern Africa and the North Sea. South African Journal of Zoology 23: 215-223.

Gerlach S.A. 1950. Über einige Nematoden aus der Familie der Desmodoriden. Zoologischer Anzeiger 145: 178-198.

Gerlach S.A. 1952. Nematodes aus dem Küstengrundwasser. Abhandlungen der MathematischNaturwissenschaftlichen Klasse 6: 315-372.

Gerlach S.A. 1956. Neue nematoden aus dem kustengrundwasser des Golfes de Gascogne (Biskaya). Vie et Milieu 6: 426-434.

Gerlach S.A. 1963. Freilebende Meeresnematoden von den Malediven II. Kieler Meeresforschungen Sonderheft 19: 67-113.

Gerlach S.A. 1964. Freilebende Nematoden aus dem Roten Meer. Kieler Meereforschungen Sonderheft $20: 18-34$.

Gerlach S.A. \& Riemann F. 1973. The Bremerhaven checklist of aquatic nematodes. A catalogue of Nematoda Adenophorea excluding the Dorylaimida. Kommissionsverlag Franz Leuwer, Bremen.

Hausdorf B. 2011. Progress toward a general species concept. Evolution 65 (4): 923-931. http://dx.doi. org/10.1111/j.1558-5646.2011.01231.x

Hodda M. 2011. Phylum Nematoda Cobb 1932. In: Zhang Z.-Q. (ed.) Animal biodiversity: An outline of higher-level classification and survey of taxonomic richness. Zootaxa 3148: 63-95.

Hope D. \& Murphy D.G. 1972. A Taxonomic Hierarchy and Checklist of the Genera and Higher Taxa of Marine Nematodes. Smithsonian Contributions to Zoology 137, Smithsonian Institution Scholarly Press, Washington. http://dx.doi.org/ 10.5479/si.00810282.137

Inglis W.G. 1963. New marine nematodes from off the coast of South Africa. Bulletin of the British Museum (Natural History) Zoology 10 (9): 529-552.

Inglis W.G. 1968. Interstitial nematodes from St. Vincent's Bay, New Caledonia. In: Expédition Française sur les récifs coralliens de la Nouvelle Calédonie. Volume 2: 29-74. Éditions de la Fondation Singer-Polignac, Paris.

Jensen P. 1985. The nematode fauna in the sulphide-rich brine seep and adjacent bottoms of the East Flower Garden, NW Gulf of Mexico. I. Chromadorida. Zoologica Scripta 14 (4): 247-263. http://dx.doi. org/10.1111/j.1463-6409.1985.tb00195.x 
Kampfer S., Sturmbauer C. \& Ott J. 1998. Phylogenetic Analysis of rDNA Sequences from Adenophorean Nematodes and Implications for the Adenophorea-Secernentea Controversy. Invertebrate Biology 117 (1): 26-36. http://dx.doi.org/10.2307/3226849

Leduc D. \& Verschelde D. 2013. One new genus and two new free-living nematode species (Desmodorida, Desmodoridae) from the continental margin of New Zealand, Southwest Pacific Ocean. Zootaxa 3609 (3): 274-290. http://dx.doi.org/10.11646/zootaxa.3609.3.2

Lorenzen S. 1994. The phylogenetic Systematics of Freeliving Nematodes. The Ray Society, London.

Maria T.F., Morgado-Esteves A., Smol N., Vanreusel A. \& Decraemer W. 2009. Chromaspirina guanabarensis sp. n. (Nematoda: Desmodoridae) and a new illustrated dichotomous key to Chromaspirina species. Zootaxa 2092: 21-36.

Maria T.F., Smol N. \& Esteves A.M. 2014. Two new species of Metachromadora (Nematoda: Desmodoridae) from Guanabara Bay, Rio de Janeiro, Brazil, and a revised dichotomous key to the genus. Journal of the Marine Biological Association of the United Kingdom 94 (1): 105-114. http:// dx.doi.org/10.1017/S0025315413001161

Micoletzky H. 1922. Die freilebenden Erd-Nematoden mit besonderer Berücksichtigung der Steiermark und der Bukowina, zugleich mit einer Revision sämtlicher, nicht mariner, freilebender Nematoden in Form von Genus-Beschreibungen und Bestimmungsschlusseln. Archiv für Naturgeschichte Berlin Abteilung A 87 (8): 1-649.

Muthumbi A.W. \& Vincx M. 1999. Microlaimidae (Microlaimoidea: Nematoda) from the Indian Ocean: description of nine new and known species. Hydrobiologia 397: 39-58. http://dx.doi. org/10.1023/A:1003686212934

Ndaro S.G.M. \& Ólafsson E. 1999. Soft-bottom fauna with emphasis on nematode assemblage structure in a tropical intertidal lagoon in Zanzibar, eastern Africa: I. Spatial variability. Hydrobiologia 405: 133148. http://dx.doi.org/10.1023/A:1003874122971

Ott J.A. 1972. Twelve New Species of Nematodes from an Intertidal Sandflat in North Carolina. Internationale Revue der Gesamten Hydrobiologie und Hydrographie 57 (3): 463-496. http://dx.doi. org/10.1002/iroh.19720570307

Ott J.A. 1996. Sulphide ectosymbioses in shallow marine habitats. In: Uiblein F., Ott J.A. \& Stachowitsch M. (eds) Deep-sea and extreme shallow-waters habitats: affinities and adaptations: 369382. Biosystematics and Ecology Series 11, Austrian Academy of Science Press, Vienna.

Ott J.A., Bauer-Nebelsick M. \& Novotny V. 1995. The genus Laxus Cobb, 1894 (Stilbonematinae: Nematoda): description of two new species with ectosymbiotic chemoautotrophic bacteria. Proceedings of the Biological Society of Washington 108 (3): 508-527.

Pastor De Ward C. 1988. Nematodos marinos de la ria Deseado (Desmodoroidea: Desmodoridae, Draconematidae), Santa Cruz, Argentina 7. Physis Secciones A, B y C 46: 61-72.

Platt H.M. \& Warwick R.M. 1988. Free-living marine nematodes. Part II. British Chromadorids. Synopses of British Fauna 38, The Linnean Society of London and The Estuarine and Brackish-water Sciences Association, Leiden.

Riemann F. \& Schrage M. 1977. Zwei neue Nematoda Desmodorida aus der Iberischen Tiefsee. Meteor Forschungsergebnisse. Reihe D: Biologie 25: 49-53.

Schulz E. 1939. Beiträge zur Morphologie und Systematik freilebender mariner Nematoden, I. Kieler Meeresforschungen Sonderheft 3: 114-121. 
Schuurmans Stekhoven J.H. 1950. The freeliving marine nemas of the Mediterranean. I. The Bay of Villefranche. Mémoires de l'Institut Royal des Sciences Naturelles de Belgique, deuxième série 37, Institut Royal des Sciences Naturelles de Belgique, Brussels.

Steiner G. 1921. Beiträge zur Kenntis mariner Nematoden. Zoologische Jahrbücher 44:1-68.

Tchesunov A.V. 2013. Marine free-living nematodes of the subfamily Stilbonematinae (Nematoda, Desmodoridae): Taxonomic review with descriptions of a few species from the Nha Trang Bay, Central Vietnam. Meiofauna Marina 20: 71-94.

Tchesunov A.V. 2014. 7.13 Order Desmodorida de Coninck, 1965. In: Schmidt-Rhaesa A(ed.) Handbook of Zoology Online: 399-434. De Gruyter, Berlin. Available from http://www.degruyter.com/view/db/ zoology [accessed 13 May 2014]

Tietjen J.H. 1991. Ecology of free-living nematodes from the continental shelf of the Central Great Barrier Reef Province. Estuarine, Coastal and Shelf Science 32 (5): 421-438. http://dx.doi.org/10.1016/02727714(91)90032-7

van Megen H., van den Elsen S., Holterman M., Karssen G., Mooyman P., Bongers T., Holovachov O., Bakker J. \& Helder J. 2009. A phylogenetic tree of nematodes based on about 1200 full-length small subunit ribosomal DNA sequences. Nematology 11 (6): 927-950. http://dx.doi.org/10.1163/156854109X456862

Venekey V., Fonseca-Genevois V.G. \& Santos P.J.P. 2010. Biodiversity of free-living marine nematodes on the coast of Brazil: a review. Zootaxa 2568: 39-66.

Verschelde D., Gourbault N.E. \& Vincx M. 1998. Revision of Desmodora with description of new Desmodorids (Nematoda) from hydrothermal vents of the Pacific. Journal of the Marine Biological Association of the United Kingdom 78 (1): 75-112. http://dx.doi.org/10.1017/S0025315400039977

Verschelde D., Nicholas W. \& Vincx M. 2006. A review of the genera Croconema Cobb, 1920 and Pseudochromadora Daday, 1899 (Nematoda, Desmodoroidea): new species from the Coasts of Kenya and Australia. Hydrobiologia 571 (1): 17-40. http://dx.doi.org/10.1007/s10750-006-0194-0

Verschelde D. \& Vincx M. 1995. Psammonema gen.n. and Pseudochromadora Daday, 1889 (Nematoda, Desmodoridae) from sandy sediments of Gazi, Kenya. Bulletin de l'Institut Royal des Sciences Naturelles de Belgique 65: 11-39.

VerscheldeD.\&Vincx M. 1996. Fournew species ofthe family Desmodoridae(Nematoda, Desmodoroidea) from Kenya. Zoologica Scripta 25 (1): 1-20. http://dx.doi.org/10.1111/j.1463-6409.1996.tb00148.x

Vincx M. 1996. Meiofauna in marine and freshwater sediments. In: Hall G.S. (ed.) Methods for the examination of organismal diversity in soils and sediments: 187-195. CAB International, Wallingford.

Vincx M. \& Gourbault N.E. 1989. Desmodoridae from the Bay of Morlaix (Brittany) and the Southern Bight of the North Sea. Cahiers de Biologie Marine 30 (1): 103-114.

Warwick R.M. 1969.Two new species of Pseudonchus Cobb (Nematoda, Choanolaimidae) from the British Coast. Cahiers de Biologie Marine 10 (4): 375-382.

Wheeler Q. 2004. Taxonomic triage and the poverty of phylogeny. Philosophical Transactions of the Royal Society B: Biological Sciences 359 (1444): 571-583. http://dx.doi.org/10.1098/rstb.2003.1452

Wieser W. 1954. Free-living marine nematodes II. Chromadoroidea. Acta Universitatis Lundensis (N. F. 2) 50, C.W.K. Gleerup, Lund.

Wieser W. \& Hopper B. 1967. Marine Nematodes of the east coast of North America. I. Florida. Bulletin of Museum of Comparative Zoology 135: 239-344. 
Manuscript received: 26 February 2014

Manuscript accepted: 11 July 2014

Published on: 15 September 2014

Topic editor: Rudy Jocqué

Desk editor: Charlotte Thionois

Printed versions of all papers are also deposited in the libraries of the institutes that are members of the EJT consortium: Muséum national d'Histoire naturelle, Paris, France; Botanic Garden Meise, Belgium; Royal Museum for Central Africa, Tervuren, Belgium; Natural History Museum, London, United Kingdom; Royal Belgian Institute of Natural Sciences, Brussels, Belgium; Natural History Museum of Denmark, Copenhagen, Denmark. 